Royal Netherlands Institute for Sea Research

This is a postprint of:

Dijk, I. van, Nooijer, L.J. de, Wolthers, M. \& Reichart, H.-J. (2017). Impacts of $\mathrm{pH}$ and $\left[\mathrm{CO}_{3}{ }^{2-}\right]$ on the incorporation of $\mathrm{Zn}$ in foraminiferal calcite. Geochimica et Cosmochimica Acta, 197, 263-277

Published version: $\underline{\text { dx.doi.org/10.1016/i.gca.2016.10.031 }}$

Link NIOZ Repository: $\underline{w w w . v l i z . b e / n l / i m i s ? m o d u l e=r e f \& r e f i d=281520 ~}$

[Article begins on next page]

The NIOZ Repository gives free access to the digital collection of the work of the Royal Netherlands Institute for Sea Research. This archive is managed according to the principles of the Open Access Movement, and the Open Archive Initiative. Each publication should be cited to its original source - please use the reference as presented.

When using parts of, or whole publications in your own work, permission from the author(s) or copyright holder(s) is always needed. 


\section{Impacts of $\mathrm{pH}$ and $\left[\mathrm{CO}_{3}{ }^{2-}\right]$ on the incorporation of $\mathrm{Zn}$ in foraminiferal calcite}

Inge van Dijk ${ }^{* 1}$, Lennart Jan de Nooijer ${ }^{1}$, Mariëtte Wolthers ${ }^{2,3}$, Gert-Jan Reichart ${ }^{1,2}$

${ }^{1}$ NIOZ - Royal Netherlands Institute for Sea Research, Department of Ocean Systems, Postbus 59, 1790 AB Den Burg, the Netherlands, and Utrecht University.

${ }^{2}$ Utrecht University, Faculty of Geosciences, Budapestlaan 4, 3584 CD Utrecht, the Netherlands.

${ }^{3}$ University College London, Department of Chemistry, 20 Gordon Street, WC1H 0AJ London, United Kingdom.

* Corresponding author: Inge.van.Dijk@nioz.nl

\section{Abstract}

The trace elemental composition of foraminiferal shell calcite is known to reflect the environment in which the shell was precipitated. Whereas conservative elements incorporated in foraminiferal shell carbonate reflect factors such as temperature $(\mathrm{Mg})$, carbonate chemistry (B) and salinity ( $\mathrm{Na})$, the nutrient type elements (Ba, $\mathrm{Cd}$, and possibly $\mathrm{Zn}$ ) are useful tools to reconstruct biogeochemical cycling and past ocean circulation. Still also nutrient-type elements will be most likely influenced by factors other than their relative concentrations. Culturing benthic foraminifera under controlled carbonate chemistry conditions allows for disentanglement of impacts of different parameters of the carbon system on the elemental composition of foraminiferal calcite. Here we show that zinc incorporation in cultured specimens of the benthic foraminifer Ammonia tepida is correlated to changes in carbonate ion

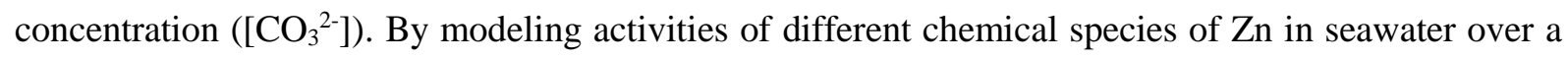
range of $\left[\mathrm{CO}_{3}{ }^{2-}\right]$, we suggest that $\mathrm{Zn}^{2+}$, rather than other relatively abundant $\mathrm{Zn}$-species (e.g. $\mathrm{ZnCO}_{3}{ }^{0}$ and $\mathrm{ZnHCO}_{3}{ }^{+}$) is taken up during biomineralization. Our results suggest that foraminiferal $\mathrm{Zn} / \mathrm{Ca}$ might be especially useful when combined with other $\left[\mathrm{CO}_{3}{ }^{2-}\right]$ proxies, enabling reconstruction of past seawater element concentrations. Conversely, when the nutrient-type element concentrations are known, incorporation of $\mathrm{Zn}$ in foraminiferal shells can be used to reconstruct past sea water carbon speciation. 


\section{Introduction}

From the active carbon cycle more than $95 \%$ is present in dissolved inorganic form in seawater (Zeebe and Wolf-Gladrow, 2001). Over geological times, changes in carbon speciation determine the amount of $\mathrm{CO}_{2}$ in the atmosphere and studies of past carbon cycling has provided important insights in the relation between climate and carbon cycling. Past marine inorganic carbon cycling can only be assessed by independently reconstructing at least two individual parameters of the so-called $\mathrm{CO}_{2}$ system (e.g. pH, $\Sigma \mathrm{CO}_{2}$, alkalinity, $\left[\mathrm{CO}_{3}{ }^{2-}\right]$ : see Zeebe and Wolf-Gladrow, 2001 for details). The interdependency of these parameters can subsequently be used to reconstruct the complete inorganic carbon system over geological timescales using any combination of the two reconstructed parameters. Combining reconstructed seawater $\mathrm{pH}$ and alkalinity (e.g. Hönisch and Hemming, 2005), for example, has resulted in reconstruction of Pleistocene dissolved $\mathrm{CO}_{2}$ concentrations, thereby allowing estimates of atmospheric $\mathrm{CO}_{2}$ levels (Hönisch et al., 2009). Accuracy and precision of these reconstructions depend on the quality and the extent to which the applied proxies are truly decoupled. The chemical composition of calcite shells produced by foraminifera is widely used for reconstructing past climate parameters. Besides functioning as a paleothermometer (e.g. using calcitic Mg/Ca; Nürnberg et al., 1996; Nürnberg, 2015; Evans et al., 2016), element concentrations (e.g. B/Ca) and stable isotope ratios (e.g. $\delta^{11}$ B) in foraminiferal shells can also reflect different parameters of the inorganic carbon system, including $\mathrm{pH}$ and $\left[\mathrm{CO}_{3}{ }^{2-}\right]$ (Sanyal et al., 1996; Raitzsch et al., 2011). The co-variation of carbon system parameters in nature often limits field calibrations and core top studies, since this obscures the impact of a single parameter on foraminiferal calcite chemistry. Moreover, such calibrations are often hampered in their application due to additional and/or unknown impacts of other parameters of the inorganic carbon system, environmental parameters (e.g. temperature, salinity) and vital effects (e.g. growth rate). For instance, application of the reported correlation between foraminiferal $\mathrm{B} / \mathrm{Ca}$ and $\left[\mathrm{CO}_{3}{ }^{2-}\right](\mathrm{Yu}$ and Elderfield, 2007; Yu et al., 2010; Rae et al., 2011) may be complicated by additional controls on boron incorporation by changes in seawater $\mathrm{pH}$ (Hemming and Hanson, 1992), DIC and/or [Ca ${ }^{2+}$ (Uchikawa et al., 2015), temperature and/or salinity (Allen et al., 2011). Experiments that separately assess impacts of different environmental parameters are therefore necessary to improve their application. 
To study the isolated impacts of carbon system parameters on foraminiferal calcite chemistry, laboratory experiments where foraminifera are cultured under controlled conditions were designed (Spero et al., 1997; Keul et al., 2013b). In such experiments, the isolated impact of e.g. pH is studied, when comparing foraminifera grown under conditions with variable versus stable $\mathrm{pH}$. Such an approach was also applied to determine the individual impacts of $\mathrm{pH}$ and $\left[\mathrm{CO}_{3}{ }^{2-}\right]$ on $\mathrm{U}$ incorporation in foraminiferal calcite, which was previously found to correlate with both $\mathrm{pH}$ and $\left[\mathrm{CO}_{3}{ }^{2-}\right]$ (Russell et al., 2004; Raitzsch et al., 2011). These experiments suggested that carbonate ion concentration rather than other parameters of the inorganic carbon system, controls foraminiferal $\mathrm{U} / \mathrm{Ca}$ and thereby highlight its potential as an independent $\left[\mathrm{CO}_{3}{ }^{2-}\right]$ proxy (Keul et al., 2013a).

Inorganic precipitation experiments previously showed that $\mathrm{Zn}$ adsorption onto calcite depends on solution pH (Zachara et al., 1991). However, core top studies (Marchitto et al., 2000; Marchitto et al., 2002) suggested that both $\mathrm{Cd} / \mathrm{Ca}$ and $\mathrm{Zn} / \mathrm{Ca}$ in foraminiferal shell carbonate covary with calcite saturation $\left(\Delta \mathrm{CO}_{3}{ }^{2-}\right)$ and might thus provide a paleoceanographic tracer for deep water masses. At the same time due to their nutrient like behavior, $\mathrm{Cd}$ and $\mathrm{Zn}$ have the potential to be used in concert to reconstruct small changes in nutrient concentrations in thermocline waters and carbonate saturation state (Bryan and Marchitto, 2010). Since these parameters are difficult to separate in the field we here calibrate incorporation of zinc $(\mathrm{Zn})$ in foraminiferal shell calcite as a function of individually varied seawater $\mathrm{pH}$ and $\left[\mathrm{CO}_{3}{ }^{2-}\right]$. We developed an experimental set-up in which these parameters are varied independently, with the newly formed calcite being analyzed for $\mathrm{Zn} / \mathrm{Ca}$ using LA-ICP-MS. Response to $\mathrm{pH}$ and $\left[\mathrm{CO}_{3}{ }^{2-}\right]$ were evaluated against inorganic chemical speciation of $\mathrm{Zn}$. 


\section{Methods}

\subsection{Foraminifera collection}

Between January and April 2013, surface sediment samples were collected during low tide at an intertidal mudflat near Texel, the Netherlands (coordinates: $53^{\circ} 0^{\prime} 21.4^{\prime \prime} \mathrm{N} ; 4^{\circ} 45^{\prime} 8.6^{\prime \prime} \mathrm{E}$ ). Samples were sieved over a $1 \mathrm{~mm}$ screen to remove the benthic macrofauna. Sediment was stored in small aquaria with seawater collected at the sampling site, thus providing a stock of foraminifera for culture experiments. Prior to the culturing experiments in summer 2013, material from the stock sediment was sieved over a $150 \mu \mathrm{m}$ screen to concentrate foraminiferal specimens of the species Ammonia tepida. From the resulting $>150 \mu \mathrm{m}$ size fraction, living specimens characterized by yellow cytoplasm and pseudopodial activity, were selected for the culturing experiments.

\subsection{Seawater preparation}

Surface water (salinity $=35.2)$ from the North Atlantic was filtered $(0.2 \mu \mathrm{m}$ pore-size $)$ and used as a basis for production of approximately $10 \mathrm{~L}$ of stock culture media. Since natural $\mathrm{Zn} / \mathrm{Ca}$ of surface seawater is relatively low (on average $4.4 \mu \mathrm{mol} / \mathrm{mol}$; Boyle, 1981; Marchitto et al., 2002), $\mathrm{Zn}$ concentration of the culture water was increased by adding $2.000 \mu \mathrm{mol}$ of $\mathrm{Zn} \mathrm{ICP}$ standard $(1000 \mathrm{mg} / \mathrm{L}$, $\mathrm{Zn}\left(\mathrm{NO}_{3}\right)_{2}$ in $\mathrm{HNO}_{3} 2-3 \%$ CentiPUR) to the stock solution. This increases the $\mathrm{Zn} / \mathrm{Ca}$ of the culture water approximately 15 times compared to average open ocean seawater [Zn]. Increasing the element to calcium ratio of surface seawater [Zn] below $0.1 \mathrm{mg} / \mathrm{L}$ does not influence survival and chamber addition rates of the miliolid foraminifera Pseudotriloculina rotunda (Nardelli et al., 2013). For Ammonia tepida, increasing the heavy metal element (e.g. Ni) to calcium ratio of surface seawater less than 20 times does not influence growth and morphology (Munsel et al., 2010). The pH of this stock solution was increased to 8.1 by adding a small volume $(\sim 5 \mathrm{ml})$ of $0.1 \mathrm{M} \mathrm{NaOH}$. Subsamples were taken to determine DIC and alkalinity of the stock solution, which was stored in a $10 \mathrm{~L}$ Nalgene container at $10^{\circ} \mathrm{C}$ and placed in the dark. Eight volumes of $750 \mathrm{ml}$ of this stock solution were manipulated with one of two different carbonate system treatments, resulting in four $750 \mathrm{ml}$ bottles per seawater treatment. The advantage of using a single stock solution for all treatments is that they will have identical seawater $\mathrm{Zn} / \mathrm{Ca}$. 


\subsubsection{Carbonate and pH manipulation}

In the first treatment, the $\mathrm{pH}$ stable treatment, seawater was manipulated to derive media with varying $\left[\mathrm{CO}_{3}{ }^{2-}\right]$, while keeping a similar $\mathrm{pH}$. This was accomplished by addition of pre-defined amounts of $\mathrm{NaHCO}_{3}(30-265 \mathrm{mg})$ to four $750 \mathrm{ml}$ bottles filled with seawater from the stock solution. The experimental range included one treatment with $\left[\mathrm{CO}_{3}{ }^{2-}\right]$ lower than the stock solution and, therefore, seawater was acidified with $\mathrm{HCl}$ and bubbled with nitrogen to lower DIC by $\mathrm{CO}_{2}$ outgassing. The [DIC] was then increased to the target value by addition of $\mathrm{NaHCO}_{3}$. For all four treatments, added volumes of [DIC] were estimated using CO2SYS software (Pierrot et al., 2006) to relate the inorganic carbon chemistry to target atmospheric $\mathrm{CO}_{2}$ concentrations (i.e. 180, 760, 1400 and $2000 \mathrm{ppm}$ ), representing pre-industrial, predicted concentration for the end of $21^{\text {st }}$ century, and two extreme greenhouse conditions. Pre-mixed gasses with exactly these concentrations were subsequently used during the incubations.

For the second treatment, the acidification experiment, four 750 ml-bottles were filled with seawater from the stock solution and addition of a small volume $(\sim 0.5 \mathrm{ml}) 0.1 \mathrm{M} \mathrm{HCl}$ or $0.1 \mathrm{M} \mathrm{NaOH}$ to obtain media with a range of $\mathrm{pH}$ values, whilst keeping a relatively constant [DIC]. Bottles with teflon lining were used to store both sets of treatment solutions without headspace at $7{ }^{\circ} \mathrm{C}$ in the dark until start of the culture experiments.

\subsection{Culture set-up}

Four air tight incubators (each with a volume of approximately $10 \mathrm{~L}$ ) were installed in a climate chamber with an ambient, constant temperature of $25^{\circ} \mathrm{C}$. Incubators were placed in a cabinet, with a day-night cycle of 12 hours:12 hours (300 lux) and connected to four different $\mathrm{CO}_{2}$ enriched air premixes corresponding with the equilibrium $p \mathrm{CO}_{2}$ of the treatments $\left(180,760,1400\right.$ and $\left.2000 \mathrm{ppm} \mathrm{CO}_{2}\right)$. Prior to entering the $10 \mathrm{~L}$ incubators, gas was bubbled through a vessel with deionized water to humidify the gasses flowing into the incubators, minimizing evaporation of the culture media. In each of the four incubators, two $500 \mathrm{ml}$-bottles containing stock media from both seawater manipulations were stored under these conditions for 4 weeks prior to the start of the experiment to serve as pre-equilibrated stock solutions to be used to replace the foraminiferal culture media. At the start of the culture experiments, 
Petri dishes containing approximately $20 \mathrm{ml}$ of medium and 5-6 foraminiferal specimens from either one of the stocks were placed (Fig. 1) in each incubator, consequently resulting in 10-17 foraminifera per seawater medium per $\mathrm{CO}_{2}$ treatment.

At the start of the experiment, pictures of individual foraminifera were taken with a DFC420 Leica camera coupled to a M165C Leica microscope to determine amount of chambers per individual at the beginning of the experiment. We were able to identify and recognize our specimens since there were only 5-6 individuals per Petri dish, and every specimen has unique characteristics for recognition (chamber shape, small (coiling) malformations, test diameter, etc.). Twice a week the foraminifera were fed with concentrated Dunaliella salina cells. The cultured algal cells were centrifuged three times for 2 minutes at $2000 \mathrm{rpm}$, after which the solvent was siphoned off and replace with de-ionzed water after every centrifuge step in order to discard the algae culture media. The resulting Dunaliella cells were freeze-dried to remove any remaining solvent and diluted in $1 \mathrm{ml}$ of treatment water, resulting in 8 different batches of $1 \mathrm{ml}$ feeding solution. Once a week the culture media were replaced with new equilibrated seawater from the stocks kept in the same incubator. Twice a week, subsamples were taken from the culture water stocks for $\mathrm{pH}$ and once every two weeks for DIC and alkalinity analyses. Every time the incubator was opened, the $\mathrm{CO}_{2}$ premix flow rate was increased from $2 \mathrm{~L} /$ hour to $60 \mathrm{~L} /$ hour for approximately 60 minutes to quickly replace the air within the incubators, thereby minimizing fluctuations in atmospheric $p \mathrm{CO}_{2}$ during the culturing experiment. After 6 weeks, all specimens were harvested and photographed again to determine the number of newly grown chambers for each treatment.

\subsection{Analytical methods}

\subsubsection{Carbonate system parameters}

$\mathrm{pH}$ of the different treatments was measured twice a week using a $\mathrm{pH}$ meter (pH110, VWR), to assess the stability of the carbonate system during the experiment. The stock seawater (North Atlantic surface seawater) was subsampled twice for $\mathrm{pH}$, TA and DIC measurements, prior to culture treatment manipulations. Subsamples of the culture media were taken in duplicate to determine DIC concentrations and total alkalinity (TA) twice a week, starting after the pre-incubation period of four 
weeks. In order to analyze the DIC of the different treatments, subsamples were collected in headspace vials containing a saturated $\mathrm{HgCl}_{2}$ solution $\left(10 \mu \mathrm{l} \mathrm{HgCl}_{2} / 10 \mathrm{ml}\right.$ sample). DIC measurements were performed on an autoanalyzer TRAACS 800 spectrometric system (Stoll et al., 2001). These analyses require only a small amount of sample, while yielding high accuracy $( \pm 2 \mu \mathrm{mol} / \mathrm{kg})$ and precision $( \pm 1.5$ $\mu \mathrm{mol} / \mathrm{kg}$ ). Subsamples for TA analysis were collected in $50 \mathrm{ml}$ Falcon tubes and stored after addition of a small volume of saturated $\mathrm{HgCl}_{2}$ solution $\left(10 \mu \mathrm{l} \mathrm{HgCl}_{2} / 10 \mathrm{ml}\right.$ sample). TA was determined using the standard operating procedure for open cell potentiometric titration (Dickson et al., 2007; SOP 3b), using an automatic titrator (Metrohm 888, Titrando), a high accuracy burette $( \pm 0.001 \mathrm{~mL})$, a thermostated reaction vessel $\left(25^{\circ} \mathrm{C}\right)$ and a combination $\mathrm{pH}$ glass electrode (Metrohm 6.0259.100). TA values were calculated by a non-linear least-squares fit to the titration data (Dickson et al., 2007, SOP 3b) in a custom-made script in the open source programming framework R. Quality assurance involved regular analysis of Certified Reference Materials (CRM) obtained from the Scripps Institution of Oceanography (Dickson et al., 2003). The average relative external precision of the TA measurements is $4.64 \%$.

Other carbonate system parameters (including $\left[\mathrm{CO}_{3}{ }^{2-}\right]$ ) were calculated using the average DIC and TA values per treatment and the software CO2SYS v2.1, adapted to Excel by Pierrot et al. (2006). With the equilibrium constants for K1 and K2 of Mehrbach et al. (1973), refitted by Dickson and Millero (1987), we were able to estimate $\left[\mathrm{CO}_{3}{ }^{2-}\right]$ and $\Omega_{\mathrm{CALCITE}}$ and compare calculated atmospheric $\mathrm{CO}_{2}$ and $\mathrm{pH}$ values to the premix and measured values.

\subsubsection{Seawater zinc and calcium analysis using SF-ICP-MS}

Culture media were subsampled $(1 \mathrm{~mL})$, and diluted 300 times with $0.1 \mathrm{M} \mathrm{HNO}_{3}$ before measuring the media's minor and major element compositions in triplicate using an Element-2 sector field double focusing Inductive Coupled Mass spectrometry (SF-ICP-MS; Thermo Scientific, Bremen, Germany) run in medium-resolution mode $(\mathrm{m} / \Delta \mathrm{m}=3000)$ to avoid the effect of mass interferences (e.g. ${ }^{40} \mathrm{Ca}+{ }^{26} \mathrm{Mg}$ ). The inlet of the mass spectrometer was equipped with a teflon microflow nebulizer and a Peltier cooled spray chamber to maximize stability of the signal. Calcium concentrations were calculated using an external calibration method with seawater matrix-matched standards. External precisions 
(RSD) are $6 \%$ for ${ }^{25} \mathrm{Mg},{ }^{88} \mathrm{Sr}$ and ${ }^{43} \mathrm{Ca}$. We obtained an average $\left[\mathrm{Mg}^{2+}\right]$ of $47 \pm 2 \mathrm{mmol} / \mathrm{kg},\left[\mathrm{Sr}^{2+}\right]$ of $50 \pm 6$ $\mu \mathrm{mol} / \mathrm{kg}$ and $\left[\mathrm{Ca}^{2+}\right] 8.4 \pm 0.3 \mathrm{mmol} / \mathrm{kg}$ for all treatments (Table 2).

Zn concentrations were determined by pre-concentration over an in-house build ion exchange column

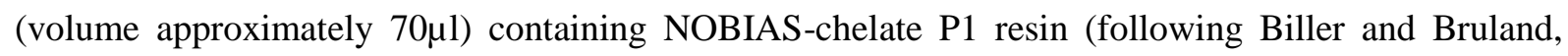
2012). Subsamples of $30 \mathrm{ml}$ were adjusted prior to pre-concentration to a $\mathrm{pH}$ of $6.5 \pm 0.2$ using a $3.7 \mathrm{M}$ ammonium acetate buffer. Each column was conditioned with $0.05 \mathrm{M}$ ammonium acetate buffer for 1 minute after which the seawater was loaded for approximately 20 minutes. After loading the column with the sample it was rinsed with $0.05 \mathrm{M}$ ammonium acetate buffer for 2 minutes. The columns were eluted with $\sim 1.5 \mathrm{ml} 1 \mathrm{M} \mathrm{HNO}_{3}$ and the eluent was analyzed in triplicate on the SF-ICP-MS run in medium-resolution mode. External precision for obtained $\left[\mathrm{Zn}^{2+}\right]$ was $5.19 \%$, and we obtained an average $\left[\mathrm{Zn}^{2+}\right]$ of $0.036 \mathrm{mg} / \mathrm{L}$ or $554 \pm 21 \mathrm{nM}$ (Table 2), which is over 100 times higher than natural deep seawater concentrations, based on global deep water Si:Zn relationship (Marchitto et al., 2000). This concentration of $\mathrm{Zn} / \mathrm{Ca}$ sw (average of $66 \pm 3 \mu \mathrm{mol} / \mathrm{mol}$ ) is approximately $15 \mathrm{x}$ higher than average surface seawater (4.4 $\mu \mathrm{mol} / \mathrm{mol}$; Boyle, 1981; Marchitto et al., 2000). Still, this concentration is not considered to be toxic to foraminifera (Nardelli et al., 2013).

\subsubsection{Elemental concentrations in foraminiferal calcite}

After termination of the experiment, foraminiferal shells were cleaned by adding $\mathrm{pH}$ buffered sodium hypochloride $(15 \% \mathrm{NaOCl})$ to microvials with individual foraminifera to remove organic material. After incubation for 20 minutes, samples were rinsed three times with ultrapure water, then dried in a laminar flow cabinet and positioned on a stub. Element concentrations of individual chambers were analyzed by Laser Ablation-ICP-MS (Reichart et al., 2003). To determine foraminiferal $\mathrm{Zn} / \mathrm{Ca}$, the laser system (NWR193UC, New Wave Research) at the Royal NIOZ was equipped with a 2-volume cell (New Wave Research), characterized by wash-out time of 1.8 seconds (1\% level) and hence allowing to detect variability of obtained $\mathrm{Zn} / \mathrm{Ca}$ within chamber walls. Single chambers were ablated in a helium environment using a circular laser spot with a diameter of $80 \mu \mathrm{m}$. All foraminiferal samples were ablated with an energy density of $1 \pm 0.1 \mathrm{~J} / \mathrm{cm}^{2}$ with a repetition rate of $5 \mathrm{~Hz}$. The aerosol was transported with a 
helium/argon flow into the quadrupole ICP-MS (iCAP-Q, Thermo Scientific). Monitored masses included ${ }^{23} \mathrm{Na},{ }^{24} \mathrm{Mg},{ }^{25} \mathrm{Mg},{ }^{26} \mathrm{Mg},{ }^{27} \mathrm{Al},{ }^{43} \mathrm{Ca},{ }^{44} \mathrm{Ca},{ }^{55} \mathrm{Mn},{ }^{66} \mathrm{Zn}$, and ${ }^{88} \mathrm{Sr} .{ }^{66} \mathrm{Zn}$ is free of interferences when measuring calcium carbonate and SRM NIST glass standards, contrary to ${ }^{67} \mathrm{Zn}$ and ${ }^{68} \mathrm{Zn}$ (Jochum et al., 2012). Zn and Ca intensities over time were integrated with Thermo Qtegra software, avoiding potential contamination or diagenesis of the outer or inner layer of calcite by monitoring the Al- and Mn-signals, resulting in determined $\mathrm{Zn} / \mathrm{Ca}$ of the experimental calcite only (Fig. 2). Due to the low $\mathrm{Zn}$ incorporation in pre-experimental (field) chambers, we could also distinguish and exclude older chambers by absence of a detectable Zn profile. Calibration was performed against SRM NIST612 glass standard, at an energy density of $5 \pm 0.1 \mathrm{~J} / \mathrm{cm}^{2}$, with ${ }^{43} \mathrm{Ca}$ as an internal standard. Using a different energy density between foraminiferal calcite and glass standard has been shown to not affect the analyses (Dueñas-Bohórquez et al., 2009). NIST612 is a suitable calibration standard when measuring $\mathrm{Zn} / \mathrm{Ca}$, since $\mathrm{Zn}$ concentration of this standard is relatively close (39.1 ppm) to that in the foraminiferal calcite from the experiments used here. To increase precision and accuracy, we applied a linear drift correction over the series of measurements. Relative precision of the analyses (relative standard deviation (RSD) of all NIST612) is $3 \%$ for ${ }^{25} \mathrm{Mg}, 3 \%$ for ${ }^{88} \mathrm{Sr}$ and $2 \%$ for ${ }^{66} \mathrm{Zn}$. In total, 162 chambers were analyzed for eight experimental conditions, resulting in 10-26 single chamber measurements per condition.

We calculated the standard deviation $(\mathrm{SD}), \mathrm{RSD}$ and standard error $\left(\mathrm{SD} / \mathrm{V}_{\mathrm{n}}\right.$; $\left.\mathrm{SE}\right)$ per treatment. The partitioning coefficient of an element $(\mathrm{E})$ between seawater and foraminiferal calcite is expressed as $\mathrm{D}_{\mathrm{E}}$ $=\left(\mathrm{E} / \mathrm{Ca}_{\mathrm{CALClTE}}\right) /\left(\mathrm{E} / \mathrm{Ca} \mathrm{a}_{\mathrm{sw}}\right)$. Partion coefficients $\left(\mathrm{D}_{\mathrm{Mg}}, \mathrm{D}_{\mathrm{Sr}}\right.$ and $\left.\mathrm{D}_{\mathrm{Zn}}\right)$ and element versus calcium ratio ( $\left.\mathrm{Zn} / \mathrm{Ca}_{\text {CaLCITE}}\right)$ were statistically compared using a two-sided T-test with 95\% confidence levels. This also allows for the calculation of $95 \%$ confidence intervals over the average per treatment. F-tests were used to compare the variance in $\mathrm{Zn} / \mathrm{Ca}$ values of the $\mathrm{pH}$ Stable and Acidification treatment $(\alpha=0.05)$. 


\section{Results}

\subsection{Calcitic element concentrations}

Average elemental ratios in foraminiferal calcite of newly formed chambers (summarized in Table 3) from all treatments were $2.10 \pm 0.38 \mathrm{mmol} / \mathrm{mol}$ for $\mathrm{Mg} / \mathrm{Ca}, 1.36 \pm 0.13 \mathrm{mmol} / \mathrm{mol}$ for $\mathrm{Sr} / \mathrm{Ca}$ and ranges

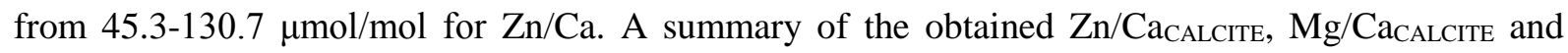
$\mathrm{Sr} / \mathrm{Ca}_{\mathrm{CAlCITE}}$ values are shown in Table 4 and Fig. 3. The relative standard deviations (RSD) of the different elements varies between $15.3-22.2 \%(\mathrm{Mg} / \mathrm{Ca}), 6.8-11.9 \%(\mathrm{Sr} / \mathrm{Ca})$ and $11.5-28 \%(\mathrm{Zn} / \mathrm{Ca})$. For $\mathrm{Mg} / \mathrm{Ca}_{\text {CALCITE }}$ (ranging from 1.71-2.48 mmol/mol) there was no siginifcant relation with any of the seawater carbonate parameters ( $\mathrm{pH},\left[\mathrm{CO}_{3}{ }^{2-}\right]$, TA and DIC). Sr/Cacalcite of $A$. tepida varies between $1.31-1.40 \mathrm{mmol} / \mathrm{mol}$ over both treatments. The partion coefficient $\mathrm{D}_{\mathrm{Sr}}$ significantly changes over a range of either $\left[\mathrm{CO}_{3}{ }^{2-}\right]$, TA and DIC (Fig. 4), while there is no significant relation with $\mathrm{pH}(\mathrm{p}>0.25)$.

\subsection{Zn/Ca variability}

The precision of $\mathrm{Zn} / \mathrm{Ca}$ for the calibration standard (2\%) was much smaller than the observed variability between measurements on chambers from the same treatment, which show a relative standard deviation of $11.5-28.0 \%$. Foraminiferal $\mathrm{Zn} / \mathrm{Ca}$ values from the variable $\mathrm{pH}$ treatments vary between 75.1 and $121.2 \mu \mathrm{mol} / \mathrm{mol}$, and $\mathrm{Zn} / \mathrm{Ca}$ of foraminifera cultivated at stable $\mathrm{pH}$ lies between 45.3 and 130.7 $\mu \mathrm{mol} / \mathrm{mol}$ (Fig. 5). When plotting $\mathrm{Zn}$ incorporation as a function of either TA or DIC (Fig. 5a, b), $\mathrm{Zn} / \mathrm{Ca} a_{\text {CALCITE }}$ decreases with both increasing TA and DIC in the $\mathrm{pH}$ stable treatment, resulting in an overall correlation with both these parameters $(\mathrm{p}<0.05)$. However, average $\mathrm{Zn} / \mathrm{Ca}$ CALCITE varies strongly within the Acidification experiment, over a narrow range in TA and DIC. When plotting $\mathrm{Zn} / \mathrm{Ca}$ CALCite versus $\mathrm{pH}$ (Fig. 5c), we observe a large range in $\mathrm{Zn} / \mathrm{Ca}$ values $(45.3-130.7 \mu \mathrm{mol} / \mathrm{mol})$ when $\mathrm{pH}$ remains relatively stable (7.9-8.08). When comparing the variance in $\mathrm{Zn} / \mathrm{Ca}$ values for the $\mathrm{pH}$ Stable group with the Acidification group using a F-test, we observe that the variance of the Acidification group is significantly smaller than the $\mathrm{pH}$ Stable group (left-sided F-test, $\alpha=0.05$ ). This implies that the observed 
261 variation in $\mathrm{Zn}$ incorporation is not controlled by $\mathrm{pH}$, but rather by another parameter of the inorganic 262 carbon system that somewhat covaries with $\mathrm{pH}$ in the Acidification treatment (e.g. $\left.\left[\mathrm{CO}_{3}{ }^{2-}\right]\right)$. The best 263 overall fit is shown when $\mathrm{Zn}$ incorporation is plotted as a function of $\left[\mathrm{CO}_{3}{ }^{2-}\right]$ (Fig. $5 \mathrm{~d}$; $\mathrm{p}<0.001$ ). We 264 obtain a highly significant relation $(\mathrm{p}<0.0005)$ when $\mathrm{D}_{\mathrm{Zn}}$ ranges from 1.9 to 0.7 and $\left[\mathrm{CO}_{3}{ }^{2-}\right]$ changes 265 from 61.9 to $1081.7 \mu \mathrm{mol} / \mathrm{kg}$ (Fig. 6). 


\section{Discussion}

\subsection{Chamber addition rates}

When comparing the average chamber addition of the foraminifera in this study (Table 3) with a foraminiferal culture study with enriched heavy metals (Munsel et al., 2010), we find almost 10-fold higher chamber addition rates per week ( 0.23 versus $0.03-0.04$ chambers per week in the 10 - and 20fold enrichment treatment). This could be due to additional stress in the study by Munsel et al. (2010), by increasing the concentration of three heavy metals $(\mathrm{Cu}, \mathrm{Ni}$ and $\mathrm{Mn})$ instead of one, or due to the introduction of fluorescent label calcein. Long-term exposure to calcein has an adverse effect on benthic foraminifera, even when using low concentration of 5mg/L (Kurtarkar et al., 2015), which may explain the overall lower new chamber yield in the culture study of Munsel et al. (2010).

\subsection{Element incorporation as a function of seawater carbonate chemistry}

Culturing foraminifera under a range of inorganic carbonate conditions shows that incorporation of $\mathrm{Zn}$ in shell calcite correlated particularly to $\left[\mathrm{CO}_{3}{ }^{2-}\right]$ (Fig. $5 \mathrm{~d}$ ), since the range in foraminiferal $\mathrm{Zn} / \mathrm{Ca}$ is relatively large when either of the other components (i.e. $\mathrm{pH}$, TA and DIC) are stable or vary over a limited range. Although co-variation is observed with pH, TA and DIC of the culture media (Fig. 6a-c) this seems an artefact from the inherent coupling of these parameters in the seawater carbonate system. This suggests that $\mathrm{Zn} / \mathrm{Ca}_{\mathrm{CALCITE}}$ provides a robust proxy for carbonate ion concentration. No impact of seawater $\mathrm{pH}$, TA and/or DIC is necessary to explain the observed trends. In contrast to $\mathrm{Zn} / \mathrm{Ca} \mathrm{CALCITE}_{\text {, }}$ foraminiferal $\mathrm{Sr} / \mathrm{Ca}$ decreases when $\left[\mathrm{CO}_{3}{ }^{2-}\right]$, TA and/or DIC increases (Fig. 4 and Table 4). $\mathrm{Sr}$ incorporation in foraminiferal calcite has been suggested to change with $\mathrm{pH}$ (Lea et al., 1999), and lateron has been proposed to react to changes in $\left[\mathrm{CO}_{3}{ }^{2-}\right]$ (Dissard et al., 2010). We show that $\mathrm{D}_{\mathrm{Sr}}$ is not significantly impacted by $\mathrm{pH}$ (Fig. 4), but by either $\left[\mathrm{CO}_{3}{ }^{2-}\right]$, DIC or TA. Foraminiferal $\mathrm{Mg} / \mathrm{Ca}(2.10 \pm 0.38$ $\mathrm{mmol} / \mathrm{mol})$ are in good agreement with the expected $\mathrm{Mg} / \mathrm{Ca}(2.17 \mathrm{mmol} / \mathrm{mol})$ based on existing temperature calibrations for this species (Toyofuku et al., 2011). Moreover, $\mathrm{Mg} / \mathrm{Ca}$ does not vary systematically with seawater carbonate chemistry, confirming results from earlier studies (e.g. DueñasBohórquez et al., 2011), but are in contrast with others (Kısakürek et al., 2008; Evans et al., 2016). 


\subsection{Intra- and inter-specimen $\mathrm{Zn} / \mathrm{Ca}$ variability}

In our study we observed appreciable intra- and/or inter-specimen variability in $\mathrm{Zn} / \mathrm{Ca}$ CALCITE. The relative standard deviation (RSD) of measured $\mathrm{Zn} / \mathrm{Ca}$ CALCITE between specimens ranged from 11.5 to $28.0 \%$, depending on the treatment (Table 4). This variability is considerably higher than the external precision $(\mathrm{RSD}=2 \%)$, based on multiple analyses of the calibration standard (NIST612). One of the causes for this relative high variability in the $\mathrm{Zn} / \mathrm{Ca}$ of foraminifera might be laboratory contamination. $\mathrm{Zn} / \mathrm{Ca}$ CALCite has been proven challenging to measure (Bruland et al., 1978), due to the combination of generally low concentrations in calcium carbonate and potential contamination when handling samples in the laboratory. Therefore, to optimize our $\mathrm{Zn} / \mathrm{Ca}$ CALCITE measurements, we did not apply an acid leach during cleaning of the foraminiferal samples since this may increase $\mathrm{Zn} / \mathrm{Ca}$ CALCITE values (Marr et al., 2013). We also increased the initial $\mathrm{Zn}$ concentrations in the culture water and cultured foraminifera without natural sediment to avoid contamination by presence of $\mathrm{Zn}$-containing clay particles. Therefore, contamination is an unlikely cause for the observed inter- and/or intraspecimen variability in $\mathrm{Zn} / \mathrm{Ca}$. $\mathrm{Zn}$ can also be introduced in the culture vessels by the addition of food, since the growth media for algae contains measurable concentrations of $\mathrm{Zn}$. However, since we separated this culture media from the Dunaliella cells by centrifuging and freeze-drying, we assume this amount of additional $\mathrm{Zn}$ is either absent or negligible.

Another source for the variability in $\mathrm{Zn} / \mathrm{Ca}_{\mathrm{CALCITE}}$ within treatments might be the stability of the experimental set-up over time. Due to the slope of the relationship between $\mathrm{D}_{\mathrm{Zn}}$ and $\left[\mathrm{CO}_{3}{ }^{2-}\right]$ (Fig. 6), small deviations of $p \mathrm{CO}_{2}$ during the culture experiment may have caused variability in $\left[\mathrm{CO}_{3}{ }^{2-}\right]$ and thereby, minor variation in intra- and/or inter-variability of $\mathrm{Zn} / \mathrm{Ca}$ CALCITE. Relative stability of TA (RSD $<8.6 \%$ ) and [DIC] (RSD <4.4\%) during the course of the experiments (Table 1), however, suggest that variability in $\left[\mathrm{CO}_{3}{ }^{2-}\right]$ was minor. Nevertheless, changes in seawater carbonate chemistry on time scales shorter than that required to build a shell and/or single chamber could result in a heterogeneous $\mathrm{Zn}$ distribution between foraminiferal shell chambers. Even though short-term variability might not have been detected due to the frequency of the sampling, it unlikely accounts for the range in measured $\mathrm{Zn} / \mathrm{CaCALCITE}$, as this would have averaged out in the time needed for a foraminifera to add chambers. 
Variability in $\mathrm{Zn} / \mathrm{Ca}$, like other proxies based on foraminiferal carbonate, may be explained by differences in e.g. ontogeny, growth rates and biological activity (Zeebe et al., 2008; Raitzsch et al., 2010; Wit et al., 2012), which all might affect element fractionation during biomineralization (Erez, 2003; De Nooijer et al., 2014b). In a number of studies (Erez, 2003; Eggins et al., 2004; Sadekov et al., 2005; Kunioka et al., 2006; Hathorne et al., 2009; De Nooijer et al., 2014a; Branson et al., 2015) it has been shown that other elements like $\mathrm{Mg}, \mathrm{Ba}$ and $\mathrm{B}$ can be heterogeneously distributed within chamber. In our study, besides a relatively high variability in $\mathrm{Zn} / \mathrm{Ca} a_{\mathrm{CALCITE}}$, we also observed similar high $\mathrm{RSD}$ values for $\mathrm{Mg} / \mathrm{Ca}_{\mathrm{CALClTE}}(15.3-22.2 \%)$, which might indicate that $\mathrm{Zn}$ is also incorporated heterogeneously. This high variability, caused by heterogeneity in $\mathrm{Zn}$ distribution within a foraminifera might limit the precision of this potential proxy. However, it has been shown for foraminiferal $\mathrm{Mg} / \mathrm{Ca}$ Calcite that the trend between the margin of error and sample size $\left(1 / \mathrm{V}_{\mathrm{n}}\right.$; Sadekov et al., 2008; De Nooijer et al., 2014a) is in line with a more or less random distribution. Hence oversampling and statistical treatment of the data should cancel out such effects. Like $\mathrm{Mg} / \mathrm{Ca} a_{\mathrm{CALCITE}}$, the uncertainty in estimated average $\mathrm{Zn} / \mathrm{Ca} \mathrm{a}_{\mathrm{CALCITE}}$ would then also decrease exponentially with increasing sample size. Such an averaging corresponds with the within chamber-wall variability in $\mathrm{Zn}$ being primarily related to a lamellar mode of calcification (Reiss, 1960). The minimum number of specimens required for an accurate estimate of average population $\mathrm{Zn} / \mathrm{Ca}$ depends on the constraints needed for the $\left[\mathrm{CO}_{3}{ }^{2-}\right]$ concentration, following similar models as previously published for $\mathrm{Mg} / \mathrm{Ca}$ and temperature (Wit et al., 2012).

\subsection{Zinc is incorporated as $\mathrm{Zn}^{2+}$}

To explore the mechanisms underlying incorporation of $\mathrm{Zn}$ in foraminiferal calcite, activities of different species of $\mathrm{Zn}$ were modeled as a function of changing $\left[\mathrm{CO}_{3}{ }^{2-}\right]$ using the software package PHREEQC (Parkhurst and Appelo, 1999) and the standard PHREEQC llnl database. For all experimental treatments, free $\mathrm{Zn}\left(\mathrm{Zn}^{2+}\right)$ increases with increasing carbonate ion concentration. Simultaneously, activity of aqueous $\mathrm{Zn}$-carbonate complexes $\left(\mathrm{ZnCO}_{3}{ }^{0}\right.$ and $\left.\mathrm{ZnHCO}_{3}{ }^{+}\right)$decreased or remained similar over the range of $\left[\mathrm{CO}_{3}{ }^{2-}\right]$ studied here. These modeled activities were plotted against the average $\mathrm{Zn} / \mathrm{Ca}$ CALCite corresponding the $\left[\mathrm{CO}_{3}{ }^{2-}\right]$ from our treatments (Fig. 7). The incorporation of $\mathrm{Zn}$ in foraminiferal shell 
calcite increased with $\mathrm{Zn}^{2+}$ activity for both the $\mathrm{pH}$ stable and the Acidification treatments. When running the model with normal (15 times lower) [Zn], we find similar profiles for the activity of different $\mathrm{Zn}$ species. This suggests that the incorporation of $\mathrm{Zn}$ is mainly determined by the (bio-) availability of $\mathrm{Zn}$ as free $\mathrm{Zn}^{2+}$ ion, which is in turn affected by changes in $\left[\mathrm{CO}_{3}{ }^{2-}\right]$, and are not impacted by the total [Zn]. However, the slope of the relationship between $\mathrm{Zn} / \mathrm{Ca}$ CALCITE and $\mathrm{Zn}^{2+}$ activity is slightly different for the two seawater manipulations, hinting at an additional control on the incorporation of Zn. This might indicate either that $\left[\mathrm{CO}_{3}{ }^{2-}\right]$ influences other mechanisms that control $\mathrm{Zn}$ incorporation, e.g. growth rates (both chamber addition and calcification rate), metabolism, ontogeny, or that a second (carbon) parameter secondarily affects Zn-incorporation. The second possibility is less likely, due to the observed strong correlation between $\left[\mathrm{CO}_{3}{ }^{2-}\right]$ and $\mathrm{D}_{\mathrm{Zn}}(\mathrm{p}<0.0005)$. Nevertheless, we cannot exclude TA or DIC as a potential secondary, minor control on $\mathrm{Zn}$ in foraminiferal shell calcite. Of all parameters investigated here, $\mathrm{pH}$ might be the least likely to have an effect on $\mathrm{Zn}$-incorporation, since the observed change in incorporated $\mathrm{Zn}$ is largest when $\mathrm{pH}$ remains stable.

\subsection{Inorganic precipitation versus biomineralization}

Even though inorganic calcite precipitation is not directly comparable to foraminiferal calcification (Elderfield et al., 1996), comparing results of these two types of experiments may increase our understanding of some of the controls on element incorporation during biomineralization (De Nooijer et al., 2014b). Results from inorganic adsorption experiments (Zachara et al., 1991) show that the relation between calcite $\mathrm{Zn} / \mathrm{Ca}$ and $\left[\mathrm{CO}_{3}{ }^{2-}\right]$ is similar to that found here for the benthic foraminifer Ammonia tepida. Inorganically precipitated calcite crystal surfaces have a higher affinity for $\mathrm{Zn}$ as $\mathrm{pH}$ of the growth medium increases. In a study by Zachara et al. (1991) pH of different treatments was changed by manipulating DIC (although not explicitly stated in the paper), which implies that e.g. $\mathrm{NaHCO}_{3}$ was added to achieve the desired solution composition and $\mathrm{pH}$, resulting a similar anticorrelation of $\mathrm{pH}$ and $\left[\mathrm{CO}_{3}{ }^{2-}\right]$ created in the experiments presented here. However, in the experiments of Zachara et al. (1991), where the solution was in equilibrium with calcite, the calcite surface characteristics will vary with $\mathrm{pH}$. With progressively higher $\mathrm{pH}$, the surface becomes more negatively charged, enhancing the adsorption of positively charged ions such as $\mathrm{Zn}^{2+}$ (Wolthers et al., 2008). In our 
culturing study, with solutions that are supersaturated with respect to calcite, there is an opposite trend: a decrease in $\mathrm{Zn}$ association with $\mathrm{pH}$ (Fig. 5c). Clearly, the local control of the foraminifera on the calcifying fluid (De Nooijer et al., 2009; Glas et al., 2012), combined with the impact of free $\mathrm{Zn}^{2+}$ activity overrule any potential surface charge effects on $\mathrm{Zn}$ uptake. During calcification in perforate species, $\mathrm{Ca}^{2+}$ is actively taken up in the cytoplasm via transmembrane transporters, and is probably not stored in intravesuclar reservoirs (De Nooijer et al., 2014b). Our results suggest that uptake of $\mathrm{Zn}^{2+}$ follows the same pathways as $\mathrm{Ca}^{2+}$, with more $\mathrm{Zn}^{2+}$ being incorporated with increasing availability of free $\mathrm{Zn}^{2+}$. In our culture study, foraminiferal $\mathrm{D}_{\mathrm{Zn}}$ varies between 1.9 and 0.7 , while inorganically precipitated calcite has a $\mathrm{D}_{\mathrm{Zn}}$ of approximately 6 at similar temperature and pressure, but higher seawater $[\mathrm{Zn}](2120 \mathrm{nM}$; Crocket and Winchester, 1966). This suggests that foraminifera incorporate less $\mathrm{Zn}$ than expected from an a-biological perspective. Such an apparent discrimination against $\mathrm{Zn}$ is in line with uptake over a membrane as suggested above.

\subsection{The effect of calcite saturation state on $D_{\mathrm{Zn}}$}

Marchitto et al. (2005) found a positive relation between calcite saturation state, expressed as $\Delta \mathrm{CO}_{3}{ }^{2-}$ $\left(\left[\mathrm{CO}_{3}{ }^{2-}\right]_{\text {in situ }}-\left[\mathrm{CO}_{3}{ }^{2-}\right]_{\text {saturation }}\right)$ and $\mathrm{D}_{\mathrm{Zn}}$. A similar effect has been reported for other elements, like $\mathrm{D}_{\mathrm{Cd}}$ and $\mathrm{D}_{\text {ва }}$ by McCorkle et al. (1995), who showed reduced incorporation of trace metals in undersaturated waters. Apparently, the mechanics behind the relation between $\left[\mathrm{CO}_{3}{ }^{2-}\right]$ and $\mathrm{Zn}$ incorporation found in our study and the studies of Marchitto et al. (2000, 2002 and 2005) stem from two different controls. These last studies analyzed foraminiferal $\mathrm{Zn}$ in deep-sea foraminifera of core-tops in nearundersaturated seawater and argues Rayleigh fractionation causes the internal calcification reservoir to be flushed rapidly, resulting in lower $\mathrm{D}_{\mathrm{Zn}}$ due to lower calcite saturation state. In our case, the culture media were always well above calcite saturation state (lowest $\Omega=1.49$; Table 1 ). This might indicate that the influence of near-undersaturation with respect to calcite does not effect our data, in which the incorporation of $\mathrm{Zn}$ is mainly governed by the amount of bioavailability of $\mathrm{Zn}^{2+}$.

There is a distinct offset observed between estimates of Cibicidoides wuellerstorfi $\left(\mathrm{D}_{\mathrm{Zn}}=9\right.$; Marchitto et al., 2000), Cibicidoides pachyderma ( $\mathrm{D}_{\mathrm{Zn}}=22 ;$ Bryan and Marchitto, 2010), the miliolid Pseudotriloculina rotunda $\left(\mathrm{D}_{\mathrm{Zn}}=0.2-4.0\right.$; Nardelli et al., 2016) and our culture calibration for Ammonia 
tepida $\left(\mathrm{D}_{\mathrm{Zn}}=1.9-0.7\right)$. This offset could be caused by the different seawater [Zn], due to difference in fractionation in natural conditions. Nardelli et al. (2016) show that lower seawater [Zn] results in higher $\mathrm{D}_{\mathrm{Zn}}$, which could explain why $\mathrm{Zn}$ partitioning is higher in the Cibicidoides species, which probably calcified at lower (deep sea) seawater [Zn]. Furthermore, observed differences might stem from speciesspecific vital effects due to calcification strategy, contamination, study type (culturing versus fieldcalibration) and/or accuracy in determination of $\mathrm{Zn} / \mathrm{Ca}$ SEAwATER, but might also reflect an additional environmental control on $\mathrm{Zn}$ incorporation. Temperature, for instance, influences crystal growth rates (Morse et al., 2007), which consequently might have an effect on the sorption and subsequent incorporation of metals on the crystal structure. Also other environmental factors, e.g. salinity, not constrained here, might affect these partitioning coefficients.

\subsection{Paleoceanographic implications}

The relationship between $\left[\mathrm{CO}_{3}{ }^{2-}\right]$ and foraminiferal $\mathrm{Zn} / \mathrm{Ca}$ could be applied for reconstructing two types of parameters. Firstly, our results show that foraminiferal $\mathrm{Zn} / \mathrm{Ca}$ might indeed be used as a proxy for $\left[\mathrm{CO}_{3}{ }^{2-}\right]$, and furthermore, that it also is not biased by changes in $\mathrm{pH}$. However, when aiming to reconstruct $\left[\mathrm{CO}_{3}{ }^{2-}\right]$ using $\mathrm{Zn} / \mathrm{Ca}$ CALCite one must take into account the difference in behavior of $\mathrm{D}_{\mathrm{Zn}}$ versus $\left[\mathrm{CO}_{3}{ }^{2-}\right]$ due to undersaturation effect discussed in section 4.6. Furthermore, as $\mathrm{Zn}$ in ocean water follows a nutrient-like behavior, an independent estimate of past seawater [ $\mathrm{Zn}]$ is necessary. For instance, Bryan and Marchitto (2010) show that in thermocline waters, $\mathrm{Zn} / \mathrm{Ca}$ CALCITE of Cibicidoides pachyderma increases with increasing $\left[\mathrm{CO}_{3}{ }^{2-}\right]$, however, $[\mathrm{Zn}]$ is not constrained in these samples. This would allow for unravelling of past seawater composition and reconstruction of past nutrient profiles. For instance, if U/Ca (Keul et al, 2013b) and Cd/Ca (Marchitto et al., 2002) are primarily controlled by changes in $\left[\mathrm{CO}_{3}{ }^{2-}\right]$ and the element to calcium ratio $(\mathrm{E} / \mathrm{Ca})$ of the seawater, simultaneous measurement of these elements on a single foraminifera by LA-ICP-MS would results in several independent reconstructions of $\left[\mathrm{CO}_{3}{ }^{2-}\right]$. Differences between these reconstructions reflect changes in the concentrations of these elements relative to each other. When the errors of the different E/CaCALCite measurements are sufficiently low, it might be possible to reconstruct the concentrations of these elements in seawater. Future research must focus on confirming these proxies (e.g. $\mathrm{Zn} / \mathrm{Ca}, \mathrm{Cd} / \mathrm{Ca}$ and 
$\mathrm{U} / \mathrm{Ca}$ ) as being mainly controlled by $\left[\mathrm{CO}_{3}{ }^{2-}\right]$, and decreasing the error in their relationship to $\left[\mathrm{CO}_{3}{ }^{2-}\right]$. When past seawater $\mathrm{Zn}$ concentration is known, the global deep water $\mathrm{Zn}: \mathrm{Si}$ relationship [Zn] = $0.052[\mathrm{Si}]+0.79$ with $[\mathrm{Zn}]$ in $\mathrm{nmol} / \mathrm{kg}$ and $[\mathrm{Si}]$ in $\mu \mathrm{mol} / \mathrm{kg}$ (Marchitto et al., 2000) can be used to estimate past [ $\mathrm{Si}]$ (profiles) of the ocean. Moreover, since the ratio between [ $\mathrm{Zn}]$ and $[\mathrm{Cd}]$ varies between water masses, relative changes in these elements may reflect changes in oceanic circulation, as has been shown by Marchitto et al. (2002). So reconstructing seawater E/Ca by using an independent $\left[\mathrm{CO}_{3}{ }^{2-}\right]$ proxy, in theory, one will be able to reconstruct past seawater element composition and even ocean circulation.

Secondly, when past seawater $\mathrm{Zn} / \mathrm{Ca}$ is constrained, the relationship between carbonate ion concentration and $\mathrm{Zn}$ incorporation in Ammonia tepida can be used to reconstruct a change in $\left[\mathrm{CO}_{3}{ }^{2-}\right]$ from e.g. 200 to $300 \mu \mathrm{mol} / \mathrm{kg}$, which would result in an increase in foraminiferal $\mathrm{Zn} / \mathrm{Ca}$ of $9.5 \%$ (Fig. 5). In combination with a proxy for other inorganic carbonate system parameters (e.g. $\delta^{11} \mathrm{~B}$ from foraminiferal calcite for seawater pH; Hönisch et al., 2009; Sanyal et al., 1996), Zn/Ca can enable reconstruction of the complete carbon system and thereby, past atmospheric $\mathrm{CO}_{2}$. However, currently, the sensitivity of the relationship between $\mathrm{Zn} / \mathrm{Ca}$ CALCITE and $\left[\mathrm{CO}_{3}{ }^{2-}\right]$, in combination with the relative large variability in $\mathrm{Zn} / \mathrm{Ca}$ CALCITE, is too large to reconstruct meaningful changes in $\left[\mathrm{CO}_{3}{ }^{2-}\right]$ smaller than interglacial-glacial cycles. Including multiple elements with a similar type of mixed nutrient/carbonate system behavior could help to improve such reconstructions. 


\section{Conclusions}

We decoupled $\mathrm{pH}$ and carbonate ion concentration in a controlled growth experiment, culturing the benthic foraminifer Ammonia tepida. Impact of individual inorganic carbonate parameters on $\mathrm{Zn}$ incorporation in the shell calcite was determined using laser ablation ICP-MS measurements of individual shell chambers. This showed that foraminiferal $\mathrm{Zn} / \mathrm{Ca}$ decreases with increasing $\left[\mathrm{CO}_{3}{ }^{2-}\right]$, with only minor impacts of $\mathrm{pH}$, DIC and TA. Modelling $\mathrm{Zn}$ speciation in seawater showed that the amount of bioavailable zinc in seawater decreases with increasing $\left[\mathrm{CO}_{3}{ }^{2-}\right]$, in line with the observed $\mathrm{Zn} / \mathrm{Ca}$ values in the foraminiferal shells. This results confirm an earlier field calibration of $\mathrm{Zn} / \mathrm{Ca}$ values to changes in $\left[\mathrm{CO}_{3}{ }^{2-}\right]$ (Marchitto et al., 2000), and shows $\mathrm{Zn}$ incorporation to be independent from $\mathrm{pH}$. Therefore, we argue that foraminifera $\mathrm{Zn} / \mathrm{Ca}$ values, combined with an independent other $\left[\mathrm{CO}_{3}{ }^{2-}\right]$ proxy, potentially allow reconstructing past nutrient profiles. Conversely, combining foraminiferal $\mathrm{Zn} / \mathrm{Ca}$ with an other independent carbonate system proxy (for e.g. $\mathrm{pH}$ ), enables reconstruction of the complete carbon system and thereby, past atmospheric $\mathrm{CO}_{2}$. 


\section{Acknowledgments}

465 This research is funded by the NIOZ - Royal Netherlands Institute for Sea Research and the Darwin 466 Centre for Biogeosciences project "Double Trouble: Consequences of Ocean Acidification - Past, 467 Present and Future -Evolutionary changes in calcification mechanisms" and the Netherlands Earth 468 System Science Center (NESSC to GJR). MW acknowledges the U.K.'s Natural Environment 469 Research Council [fellowship \#NE/J018856/1] and funding from the Foundation for Fundamental 470 Research on Matter (FOM), which is part of the Netherlands Organization for Scientific Research 471 (NWO). We would like to thank Patrick Laan and Wim Boer for analyzing seawater elemental composition, Karel Bakker for DIC measurements and Marco Houtekamer for measuring TA of the culture media. We would like to thanks two anonymous reviewers for their constructive comments. 
References

Allen, K.A., Hönisch, B., Eggins, S.M., Yu, J., Spero, H.J. and Elderfield, H. (2011) Controls on boron incorporation in cultured tests of the planktic foraminifer Orbulina universa. Earth and Planetary Science Letters 309, 291-301.

Boyle, E.A. (1981) Cadmium, zinc, copper, and barium in foraminifera tests. Earth and Planetary Science Letters 53, 11-35.

Branson, O., Kaczmarek, K., Redfern, S.A.T., Misra, S., Langer, G., Tyliszczak, T., Bijma, J. and Elderfield, H. (2015) The coordination and distribution of B in foraminiferal calcite. Earth and Planetary Science Letters 416, 67-72.

Bruland, K.W., Knauer, G.A. and Martin, J.H. (1978) Zinc in north-east Pacific water. Nature $271,741-743$.

Bryan, S.P. and Marchitto, T.M. (2010) Testing the utility of paleonutrient proxies $\mathrm{Cd} / \mathrm{Ca}$ and $\mathrm{Zn} / \mathrm{Ca}$ in benthic foraminifera from thermocline waters. Geochemistry, Geophysics, Geosystems 11, n/a-n/a.

Crocket, J.H. and Winchester, J.W. (1966) Coprecipitation of zinc with calcium carbonate. Geochimica et Cosmochimica Acta 30, 1093-1109.

De Nooijer, L.J., Hathorne, E.C., Reichart, G.J., Langer, G. and Bijma, J. (2014a) Variability in calcitic $\mathrm{Mg} / \mathrm{Ca}$ and $\mathrm{Sr} / \mathrm{Ca}$ ratios in clones of the benthic foraminifer Ammonia tepida. Marine Micropaleontology 107, 32-43.

De Nooijer, L.J., Spero, H.J., Erez, J., Bijma, J. and Reichart, G.J. (2014b) Biomineralization in perforate foraminifera. Earth-Science Reviews 135, 48-58.

De Nooijer, L.J., Toyofuku, T. and Kitazato, H. (2009) Foraminifera promote calcification by elevating their intracellular pH. Proceedings of the National Academy of Sciences 106, 15374-15378.

Dickson, A.G., Afghan, J.D. and Anderson, G.C. (2003) Reference materials for oceanic $\mathrm{CO}_{2}$ analysis: a method for the certification of total alkalinity. Marine Chemistry 80, 185-197.

Dickson, A.G. and Millero, F.J. (1987) A comparison of the equilibrium constants for the dissociation of carbonic acid in seawater media. Deep Sea Research Part A. Oceanographic Research Papers 34, 1733-1743.

Dissard, D., Nehrke, G., Reichart, G.J. and Bijma, J. (2010) Impact of seawater $p \mathrm{CO}_{2}$ on calcification and $\mathrm{Mg} / \mathrm{Ca}$ and $\mathrm{Sr} / \mathrm{Ca}$ ratios in benthic foraminifera calcite: results from culturing experiments with Ammonia tepida. Biogeosciences 7, 81-93.

Dueñas-Bohórquez, A., da Rocha, R.E., Kuroyanagi, A., Bijma, J. and Reichart, G.-J. (2009) Effect of salinity and seawater calcite saturation state on $\mathrm{Mg}$ and $\mathrm{Sr}$ incorporation in cultured planktonic foraminifera. Marine Micropaleontology 73, 178-189. 
Eggins, S., Sadekov, A. and Dedeckker, P. (2004) Modulation and daily banding of $\mathrm{Mg} / \mathrm{Ca}$ in tests by symbiont photosynthesis and respiration: a complication for seawater thermometry? Earth and Planetary Science Letters 225, 411-419.

Elderfield, H., Bertram, C.J. and Erez, J. (1996) A biomineralization model for the incorporation of trace elements into foraminiferal calcium carbonate. Earth and Planetary Science Letters 142, 409423.

Erez, J. (2003) The source of ions for biomineralization in foraminifera and their implications for paleoceanographic proxies. Reviews in Mineralogy and Geochemistry 54, 115-149.

Evans, D., Wade, B.S., Henehan, M., Erez, J. and Müller, W. (2016) Revisiting carbonate chemistry controls on planktic foraminifera $\mathrm{Mg} / \mathrm{Ca}$ : implications for sea surface temperature and hydrology shifts over the Paleocene-Eocene Thermal Maximum and Eocene-Oligocene transition. Clim. Past 12, 819-835.

Glas, M.S., Langer, G. and Keul, N. (2012) Calcification acidifies the microenvironment of a benthic foraminifer (Ammonia sp.). Journal of Experimental Marine Biology and Ecology 424-425, 5358.

Hathorne, E.C., James, R.H. and Lampitt, R.S. (2009) Environmental versus biomineralization controls on the intratest variation in the trace element composition of the planktonic foraminifera $G$. inflata and G. scitula. Paleoceanography 24, n/a-n/a.

Hemming, N.G. and Hanson, G.N. (1992) Boron isotopic composition and concentration in modern marine carbonates. Geochimica et Cosmochimica Acta 56, 537-543.

Hönisch, B. and Hemming, N.G. (2005) Surface ocean $\mathrm{pH}$ response to variations in $p \mathrm{CO}_{2}$ through two full glacial cycles. Earth and Planetary Science Letters 236, 305-314.

Hönisch, B., Hemming, N.G., Archer, D., Siddall, M. and McManus, J.F. (2009) Atmospheric carbon dioxide concentration across the Mid-Pleistocene Transition. Science 324, 1551-1554.

Jochum, K.P., Scholz, D., Stoll, B., Weis, U., Wilson, S.A., Yang, Q., Schwalb, A., Börner, N., Jacob, D.E. and Andreae, M.O. (2012) Accurate trace element analysis of speleothems and biogenic calcium carbonates by LA-ICP-MS. Chemical Geology 318-319, 31-44.

Keul, N., Langer, G., de Nooijer, L.J. and Bijma, J. (2013a) Effect of ocean acidification on the benthic foraminifera Ammonia sp. is caused by a decrease in carbonate ion concentration. Biogeosciences 10, 6185-6198.

Keul, N., Langer, G., de Nooijer, L.J., Nehrke, G., Reichart, G.-J. and Bijma, J. (2013b) Incorporation of uranium in benthic foraminiferal calcite reflects seawater carbonate ion concentration. Geochemistry, Geophysics, Geosystems 14, 102-111.

Kısakürek, B., Eisenhauer, A., Böhm, F., Garbe-Schönberg, D. and Erez, J. (2008) Controls on shell $\mathrm{Mg} / \mathrm{Ca}$ and $\mathrm{Sr} / \mathrm{Ca}$ in cultured planktonic foraminifera, Globigerinoides ruber (white). Earth and Planetary Science Letters 273, 260-269. 
Kunioka, D., Shirai, K., Takahata, N., Sano, Y., Toyofuku, T. and Ujiie, Y. (2006) Microdistribution of $\mathrm{Mg} / \mathrm{Ca}, \mathrm{Sr} / \mathrm{Ca}$, and $\mathrm{Ba} / \mathrm{Ca}$ ratios in Pulleniatina obliquiloculata test by using a NanoSIMS: Implication for the vital effect mechanism. Geochemistry, Geophysics, Geosystems 7, n/an/a.

Kurtarkar, S.R., Saraswat, R., Nigam, R., Banerjee, B., Mallick, R., Naik, D.K. and Singh, D.P. (2015) Assessing the effect of calcein incorporation on physiological processes of benthic foraminifera. Marine Micropaleontology 114, 36-45.

Lea, D.W., Mashiotta, T.A. and Spero, H.J. (1999) Controls on magnesium and strontium uptake in planktonic foraminifera determined by live culturing. Geochimica et Cosmochimica Acta 63, 23692379.

Marchitto, T.M., Curry, W.B. and Oppo, D.W. (2000) Zinc concentrations in benthic foraminifera reflect seawater chemistry. Paleoceanography 15, 299-306.

Marchitto, T.M., Lynch-Stieglitz, J. and Hemming, S.R. (2005) Deep Pacific $\mathrm{CaCO}_{3}$ compensation and glacial-interglacial atmospheric $\mathrm{CO}_{2}$. Earth and Planetary Science Letters 231, 317336.

Marchitto, T.M., Oppo, D.W. and Curry, W.B. (2002) Paired benthic foraminiferal Cd/Ca and $\mathrm{Zn} / \mathrm{Ca}$ evidence for a greatly increased presence of Southern Ocean Water in the glacial North Atlantic. Paleoceanography 17, 10-11-10-18.

Marr, J.P., Bostock, H.C., Carter, L., Bolton, A. and Smith, E. (2013) Differential effects of cleaning procedures on the trace element chemistry of planktonic foraminifera. Chemical Geology 351 , 310-323.

McCorkle, D.C., Martin, P.A., Lea, D.W. and Klinkhammer, G.P. (1995) Evidence of a dissolution effect on benthic foraminiferal shell chemistry: $\delta^{13} \mathrm{C}, \mathrm{Cd} / \mathrm{Ca}, \mathrm{Ba} / \mathrm{Ca}$, and $\mathrm{Sr} / \mathrm{Ca}$ results from the Ontong Java Plateau. Paleoceanography 10, 699-714.

Mehrbach, C., Culberson, C.H., Hawley, J.E. and Pytkowicx, R.M. (1973) Measurement of the apparent dissociation constants of carbonic acid in seawater at atmospheric pressure. Limnology and Oceanography 18, 897-907.

Morse, J.W., Arvidson, R.S. and Lüttge, A. (2007) Calcium carbonate formation and dissolution. Chemical Reviews 107, 342-381.

Munsel, D., Kramar, U., Dissard, D., Nehrke, G., Berner, Z., Bijma, J., Reichart, G.J. and Neumann, T. (2010) Heavy metal incorporation in foraminiferal calcite: results from multi-element enrichment culture experiments with Ammonia tepida. Biogeosciences 7, 2339-2350.

Nardelli, M.P., Malferrari, D., Ferretti, A., Bartolini, A., Sabbatini, A. and Negri, A. (2016) Zinc incorporation in the miliolid foraminifer Pseudotriloculina rotunda under laboratory conditions. Marine Micropaleontology 126, 42-49.

Nardelli, M.P., Sabbatini, A. and Negri, A. (2013) Experimental chronic exposure of the foraminifer Pseudotriloculina rotunda to zinc. Acta Protozoologica 52, 193. 
Nürnberg, D. (2015) Mg/Ca Paleothermometry, in: Harff, J., Meschede, M., Petersen, S., Thiede, J. (Eds.), Encyclopedia of Marine Geosciences. Springer Netherlands, pp. 1-3.

Nürnberg, D., Bijma, J. and Hemleben, C. (1996) Assessing the reliability of magnesium in foraminiferal calcite as a proxy for water mass temperatures. Geochimica et Cosmochimica Acta 60, 803-814.

Pierrot, D., Lewis, E. and Wallace, D.W.R. (2006) MS Excel Program Developed for $\mathrm{CO}_{2}$ System Calculations, ORNL/CDIAC-105a. Carbon Dioxide Information Analysis Center, Oak Ridge National Laboratory, U.S.

Rae, J.W.B., Foster, G.L., Schmidt, D.N. and Elliott, T. (2011) Boron isotopes and B/Ca in benthic foraminifera: Proxies for the deep ocean carbonate system. Earth and Planetary Science Letters 302, 403-413.

Raitzsch, M., Dueñas-Bohórquez, A., Reichart, G.J., de Nooijer, L.J. and Bickert, T. (2010) Incorporation of $\mathrm{Mg}$ and $\mathrm{Sr}$ in calcite of cultured benthic foraminifera: impact of calcium concentration and associated calcite saturation state. Biogeosciences 7, 869-881.

Raitzsch, M., Hathorne, E.C., Kuhnert, H., Groeneveld, J. and Bickert, T. (2011) Modern and late Pleistocene $\mathrm{B} / \mathrm{Ca}$ ratios of the benthic foraminifer Planulina wuellerstorfi determined with laser ablation ICP-MS. Geology 39, 1039-1042.

Russell, A.D., Hönisch, B., Spero, H.J. and Lea, D.W. (2004) Effects of seawater carbonate ion concentration and temperature on shell $\mathrm{U}, \mathrm{Mg}$, and $\mathrm{Sr}$ in cultured planktonic foraminifera. Geochimica et Cosmochimica Acta 68, 4347-4361.

Sadekov, A., Eggins, S.M., De Deckker, P. and Kroon, D. (2008) Uncertainties in seawater thermometry deriving from intratest and intertest $\mathrm{Mg} / \mathrm{Ca}$ variability in Globigerinoides ruber. Paleoceanography 23, n/a-n/a.

Sadekov, A.Y., Eggins, S.M. and De Deckker, P. (2005) Characterization of $\mathrm{Mg} / \mathrm{Ca}$ distributions in planktonic foraminifera species by electron microprobe mapping. Geochemistry, Geophysics, Geosystems 6, n/a-n/a.

Sanyal, A., Hemming, N.G., Broecker, W.S., Lea, D.W., Spero, H.J. and Hanson, G.N. (1996) Oceanic $\mathrm{pH}$ control on the boron isotopic composition of foraminifera: Evidence from culture experiments. Paleoceanography 11, 513-517.

Spero, H.J., Bijma, J., Lea, D.W. and Bemis, B.E. (1997) Effect of seawater carbonate concentration on foraminiferal carbon and oxygen isotopes. Nature 390, 497-500.

Stoll, M.H.C., Bakker, K., Nobbe, G.H. and Haese, R.R. (2001) Continuous-Flow analysis of dissolved inorganic carbon content in seawater. Analytical Chemistry 73, 4111-4116.

Toyofuku, T., Suzuki, M., Suga, H., Sakai, S., Suzuki, A., Ishikawa, T., de Nooijer, L.J., Schiebel, R., Kawahata, H. and Kitazato, H. (2011) $\mathrm{Mg} / \mathrm{Ca}$ and $\delta^{18} \mathrm{O}$ in the brackish shallow-water benthic foraminifer Ammonia 'beccarii’. Marine Micropaleontology 78, 113-120. 
Uchikawa, J., Penman, D.E., Zachos, J.C. and Zeebe, R.E. (2015) Experimental evidence for kinetic effects on $\mathrm{B} / \mathrm{Ca}$ in synthetic calcite: Implications for potential $\mathrm{B}(\mathrm{OH})_{4}{ }^{-}$and $\mathrm{B}(\mathrm{OH})_{3}$ incorporation. Geochimica et Cosmochimica Acta 150, 171-191.

Wit, J.C., de Nooijer, L.J., Barras, C., Jorissen, F.J. and Reichart, G.J. (2012) A reappraisal of the vital effect in cultured benthic foraminifer Bulimina marginata on $\mathrm{Mg} / \mathrm{Ca}$ values: assessing temperature uncertainty relationships. Biogeosciences 9, 3693-3704.

Wolthers, M., Charlet, L. and Van Cappellen, P. (2008) The surface chemistry of divalent metal carbonate minerals; a critical assessment of surface charge and potential data using the charge distribution multi-site ion complexation model. American Journal of Science 308, 905-941.

Yu, J. and Elderfield, H. (2007) Benthic foraminiferal B/Ca ratios reflect deep water carbonate saturation state. Earth and Planetary Science Letters 258, 73-86.

Yu, J., Foster, G.L., Elderfield, H., Broecker, W.S. and Clark, E. (2010) An evaluation of benthic foraminiferal $\mathrm{B} / \mathrm{Ca}$ and $\delta^{11} \mathrm{~B}$ for deep ocean carbonate ion and $\mathrm{pH}$ reconstructions. Earth and Planetary Science Letters 293, 114-120.

Zachara, J.M., Cowan, C.E. and Resch, C.T. (1991) Sorption of divalent metals on calcite. Geochimica et Cosmochimica Acta 55, 1549-1562.

Zeebe, R.E., Bijma, J., Honisch, B., Sanyal, A., Spero, H.J. and Wolf-Gladrow, D.A. (2008) Vital effects and beyond: a modelling perspective on developing palaeoceanographical proxy relationships in foraminifera. Geological Society, London, Special Publications 303, 45-58.

Zeebe, R.E. and Wolf-Gladrow, D.A. (2001) $\mathrm{CO}_{2}$ in seawater: equilibrium, kinetics, isotopes. Gulf Professional Publishing. 


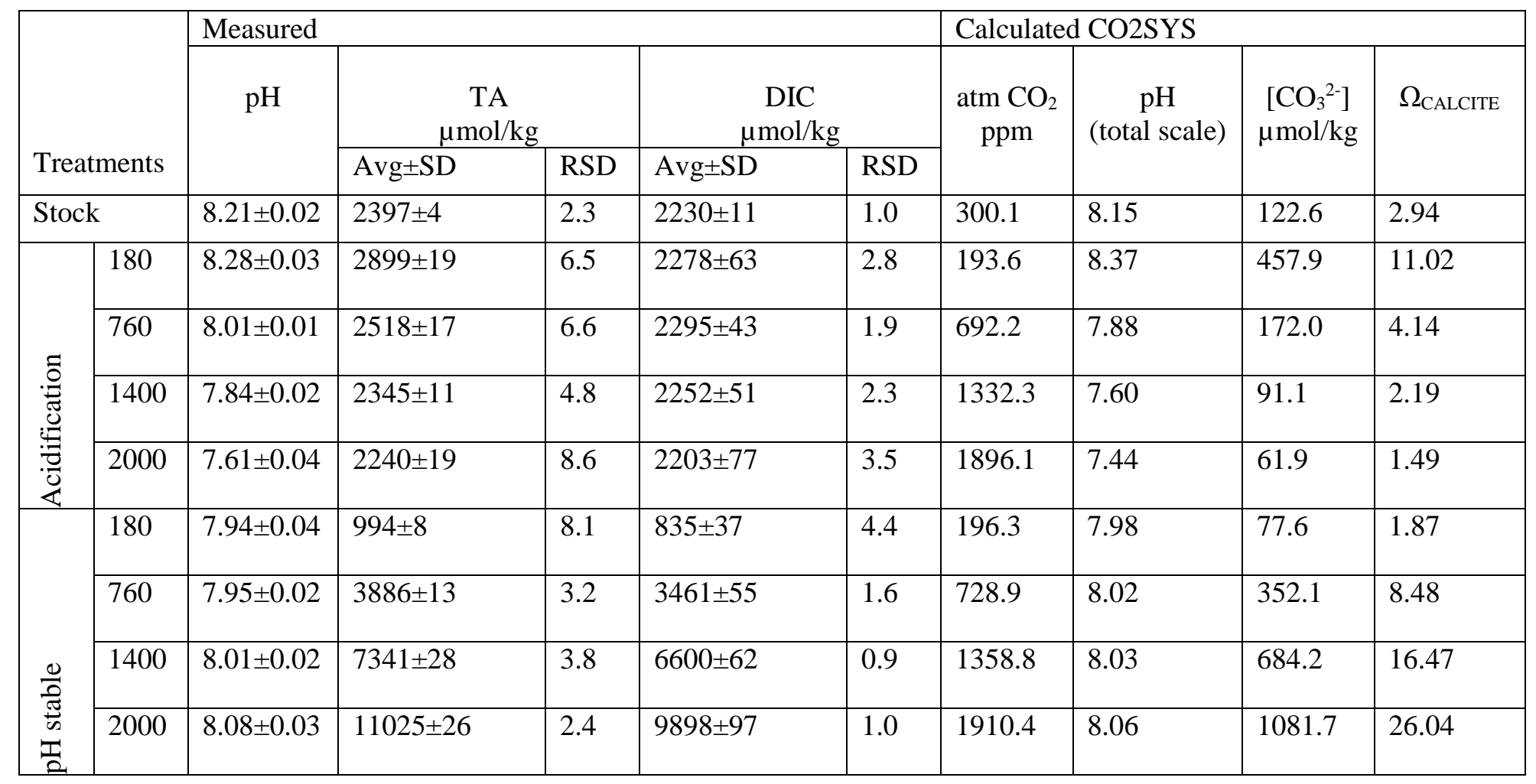

Table 1. Average (Avg) carbon parameters $(\mathrm{pH}, \mathrm{n}=12 ; \mathrm{TA}=$ Total alkalinity; $\mathrm{n}=6 \mathrm{DIC}=$ Dissolved Inorganic Carbon, $\mathrm{n}=6$ ) with (relative) standard deviation of the culture water per treatment. CO2SYS was used to calculate carbonate ion concentration $\left(\left[\mathrm{CO}_{3}{ }^{2-}\right]\right)$ and calcite saturation state $\left(\Omega_{\mathrm{CALCITE}}\right)$ and recalculate $\mathrm{pH}$ and atmospheric $\mathrm{CO}_{2}$ from measured TA and DIC. 


\begin{tabular}{|c|c|c|c|c|c|c|c|c|}
\hline \multicolumn{2}{|c|}{ Treatment } & $\begin{array}{l}{\left[\mathrm{Zn}^{2+}\right] \mathrm{sw}} \\
\mathrm{nM}\end{array}$ & $\begin{array}{l}{\left[\mathrm{Mg}^{2+}\right] \mathrm{sw}} \\
\mathrm{mM}\end{array}$ & $\begin{array}{l}{\left[\mathrm{Sr}^{2+}\right] \mathrm{sw}} \\
\mu \mathrm{M}\end{array}$ & $\begin{array}{l}{\left[\mathrm{Ca}^{2+}\right] \mathrm{sw}} \\
\mathrm{mM}\end{array}$ & $\begin{array}{l}\mathrm{Zn} / \mathrm{Ca} a_{S w} \\
\mu \mathrm{mol} / \mathrm{mol}\end{array}$ & $\begin{array}{l}\mathrm{Mg} / \mathrm{Casw} \\
\mathrm{mol} / \mathrm{mol}\end{array}$ & $\begin{array}{l}\mathrm{Sr} / \mathrm{Ca}_{\mathrm{Sw}} \\
\mathrm{mmol} / \mathrm{mol}\end{array}$ \\
\hline \multirow{4}{*}{ 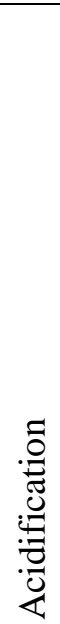 } & 180 & $\begin{array}{l}563.53 \\
\pm 12.82\end{array}$ & $\begin{array}{l}44.54 \\
\pm 1.78\end{array}$ & $\begin{array}{l}53.56 \\
\pm 3.28\end{array}$ & $\begin{array}{l}8.57 \\
\pm 0.08\end{array}$ & $\begin{array}{l}65.79 \\
\pm 2.15\end{array}$ & $\begin{array}{l}5.20 \\
\pm 0.26\end{array}$ & $\begin{array}{l}6.25 \\
\pm 0.45\end{array}$ \\
\hline & 760 & $\begin{array}{r}517.59 \\
\pm 23.65\end{array}$ & $\begin{array}{r}45.70 \\
\pm 3.20\end{array}$ & $\begin{array}{r}49.47 \\
\pm 1.35\end{array}$ & $\begin{array}{l}8.51 \\
\pm 0.44\end{array}$ & $\begin{array}{r}60.80 \\
\pm 5.89\end{array}$ & $\begin{array}{l}5.38 \\
\pm 0.65\end{array}$ & $\begin{array}{l}5.82 \\
\pm 0.46\end{array}$ \\
\hline & 1400 & $\begin{array}{l}570.72 \\
\pm 31.25\end{array}$ & $\begin{array}{l}46.87 \\
\pm 1.41\end{array}$ & $\begin{array}{l}53.46 \\
\pm 1.08\end{array}$ & $\begin{array}{l}8.68 \\
\pm 0.78\end{array}$ & $\begin{array}{r}65.73 \\
\pm 9.51\end{array}$ & $\begin{array}{l}5.41 \\
\pm 0.65\end{array}$ & $\begin{array}{l}6.17 \\
\pm 0.68\end{array}$ \\
\hline & 2000 & $\begin{array}{l}582.20 \\
\pm 67.03\end{array}$ & $\begin{array}{l}47.28 \\
\pm 2.36\end{array}$ & $\begin{array}{l}51.41 \\
\pm 1.15\end{array}$ & $\begin{array}{l}8.41 \\
\pm 0.0 .48\end{array}$ & $\begin{array}{l}69.24 \\
\pm 11.92\end{array}$ & $\begin{array}{l}5.63 \\
\pm 0.60\end{array}$ & $\begin{array}{l}6.13 \\
\pm 0.49\end{array}$ \\
\hline \multirow[b]{4}{*}{ 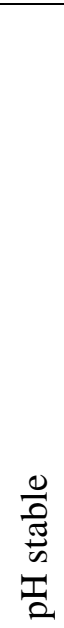 } & 180 & $\begin{array}{l}537.49 \\
\pm 5.74\end{array}$ & $\begin{array}{l}44.62 \\
\pm 1.34\end{array}$ & $\begin{array}{l}50.07 \\
\pm 3.05\end{array}$ & $\begin{array}{l}7.95 \\
\pm 0.72\end{array}$ & $\begin{array}{r}67.60 \\
\pm 6.81\end{array}$ & $\begin{array}{l}5.62 \\
\pm 0.68\end{array}$ & $\begin{array}{l}6.31 \\
\pm 0.95\end{array}$ \\
\hline & 760 & $\begin{array}{l}560.96 \\
\pm 6.42\end{array}$ & $\begin{array}{l}46.07 \\
\pm 0.46\end{array}$ & $\begin{array}{l}54.98 \\
\pm 2.97\end{array}$ & $\begin{array}{l}8.52 \\
\pm 0.62\end{array}$ & $\begin{array}{r}65.84 \\
\pm 5.50\end{array}$ & $\begin{array}{l}5.42 \\
\pm 0.45\end{array}$ & $\begin{array}{l}6.47 \\
\pm 0.82\end{array}$ \\
\hline & 1400 & $\begin{array}{l}542.4 \\
\pm 22.63\end{array}$ & $\begin{array}{r}49.79 \\
\pm 2.49\end{array}$ & $\begin{array}{r}47.99 \\
\pm 3.88\end{array}$ & $\begin{array}{l}8.56 \\
\pm 0.35\end{array}$ & $\begin{array}{r}63.43 \\
\pm 5.04\end{array}$ & $\begin{array}{l}5.84 \\
\pm 0.53\end{array}$ & $\begin{array}{l}5.62 \\
\pm 0.68\end{array}$ \\
\hline & 2000 & $\begin{array}{l}553.32 \\
\pm 13.44\end{array}$ & $\begin{array}{l}48.85 \\
\pm 0.49\end{array}$ & $\begin{array}{l}36.22 \\
\pm 1.58\end{array}$ & $\begin{array}{l}8.13 \\
\pm 0.44\end{array}$ & $\begin{array}{r}68.10 \\
\pm 4.51\end{array}$ & $\begin{array}{l}6.02 \\
\pm 0.39\end{array}$ & $\begin{array}{l}4.47 \\
\pm 0.44\end{array}$ \\
\hline
\end{tabular}

Table 2. Element concentrations and element-calcium ratios (bold) of the culture water per treatment \pm (propagating) standard deviation. 


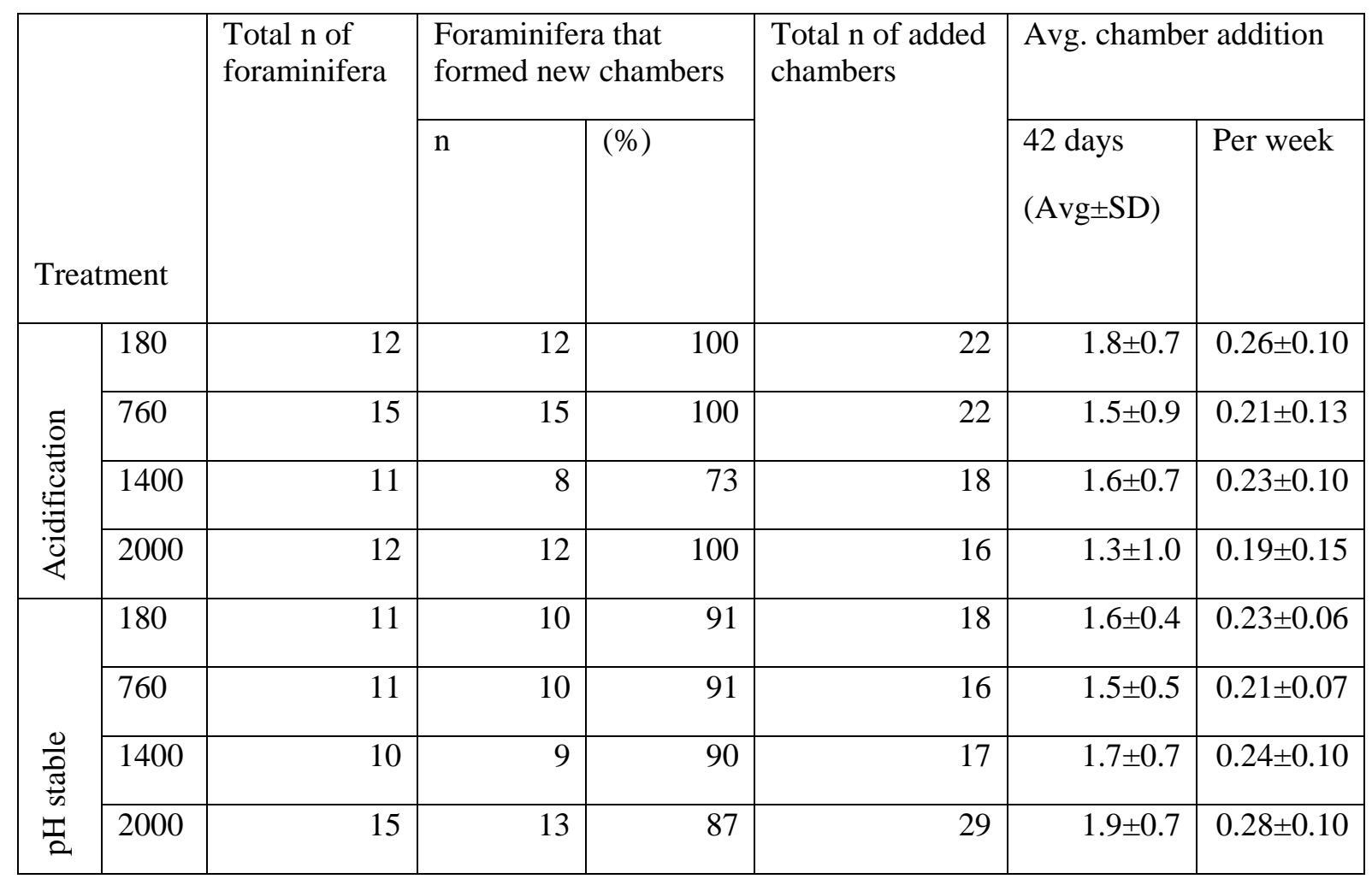

Table 3: Number of new chambers added per treatment. Average chamber addition (per week) based on linear growth. 


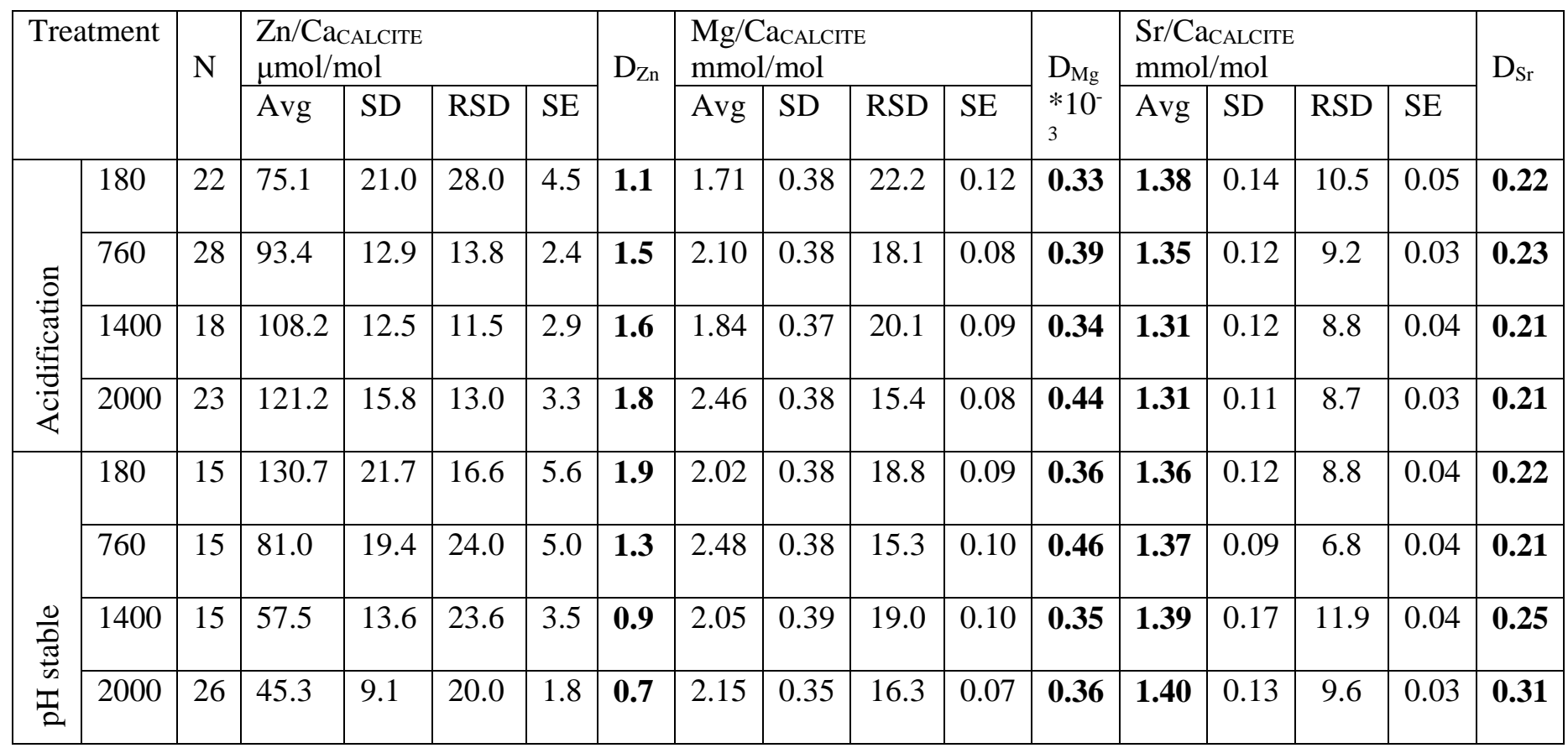

Table 4. Overview of $\mathrm{Zn} / \mathrm{Ca}, \mathrm{Mg} / \mathrm{Ca}$, and $\mathrm{Sr} / \mathrm{Ca}$ ratios in foraminiferal calcite (Avg=average;

$\mathrm{SD}=$ standard deviation; $\mathrm{RSD}=$ relative standard deviation; $\mathrm{SE}=$ standard error) results from LA-ICP-MS, and partitioning coefficients $\mathrm{D}_{\mathrm{E}}$ in bold. 
Figure 1. Culture set-up: $\mathrm{CO}_{2}$ premix connected to an air tight incubator containing two sets of culture samples and both artificial seawater treatments, 'pH stable' and 'Acidification'. The total set-up comprised four incubators, each coupled to one of four different $\mathrm{CO}_{2}$ premixes.

Figure 2. Example of a typical LA-ICP-MS analysis of a single chamber. Gas blanks are deducted from the signal in the integrated period, to obtain elemental concentration of primary calcite.

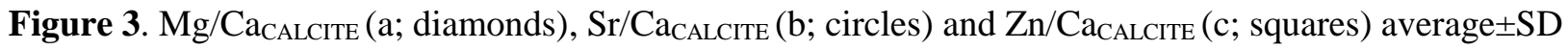
element to calcium ratios and LA-ICP-MS single measurements of both Acidification (white symbols and grey dots respectively) and $\mathrm{pH}$ Stable (red symbols and pink dots resp.) with related boxplots for all treatments $(\mathrm{A}-\mathrm{D})$.

Figure 4. $\mathrm{D}_{\mathrm{Sr}} \pm \mathrm{SD}$ of the $\mathrm{pH}$ stable (red) and Acidification (white) treatment. Top panel: $\mathrm{D}_{\mathrm{Sr}}$ versus a) Total Alkalinity (TA) and b) Dissolved Inorganic Carbon (DIC). Lower panel: $\mathrm{D}_{\mathrm{Sr}}$ versus c) $\mathrm{pH}$ and d) $\left[\mathrm{CO}_{3}{ }^{2-}\right]$. Grey dashed lines are linear regressions, $\mathrm{R}^{2}$ and $\mathrm{p}$-vales (95\% confidence) are reported in the graph.

Figure 5. $\mathrm{Zn} / \mathrm{Ca}_{\mathrm{CALCITE}}$ of the $\mathrm{pH}$ stable (red) and Acidification (white) treatment. Top panel: $\mathrm{Zn} / \mathrm{Ca}_{\mathrm{CALCITE}}$ versus a) Total Alkalinity (TA) and b) Dissolved Inorganic Carbon (DIC). Lower panel: Zn/CaCALCITE versus c) $\mathrm{pH}$ and d) $\left[\mathrm{CO}_{3}{ }^{2-}\right.$. Standard errors (solid line) and -deviations (dotted line), caused by intra and inter specimen variablity are plotted for every treatment. Grey dashed lines are linear regressions, $\mathrm{R}^{2}$ and p-vales are noted in the graph. 
Figure 6. Partitioning coefficient, $\mathrm{D}_{\mathrm{Zn}} \pm \mathrm{SD}$ of individual ablations (grey circles) and the average per treatment $(\mathrm{pH}$ stable $=$ red, Acidification $=$ white $)$. The relationship between $\mathrm{D}_{\mathrm{Zn}}(\mathrm{Y})$ and $\left[\mathrm{CO}_{3}{ }^{2-}\right](\mathrm{X})$ can be expressed as $\mathrm{Y}=\mathrm{ae}^{\mathrm{bx}}$, where $\mathrm{a}=1.86 \pm 0.38$ and $\mathrm{b}=-0.001 \pm 0.0001$ (solid line). Dashed lines indicate 95\% confidence interval.

Figure 7. $\mathrm{Zn} / \mathrm{Ca}$ in foraminiferal calcite at different activities of free $\mathrm{Zn}^{2+}$ (left panel) and $\mathrm{Zn}$-carbonate complexes (right panel; triangles $=\mathrm{ZnCO}_{3}{ }^{0}$; diamonds $=\mathrm{ZnHCO}_{3}{ }^{+}$) corresponding with the $\left[\mathrm{CO}_{3}{ }^{2-}\right]$ of the different treatments and seawater manipulations $(\mathrm{pH}$ stable $=$ red; Acidification $=$ white $)$ 


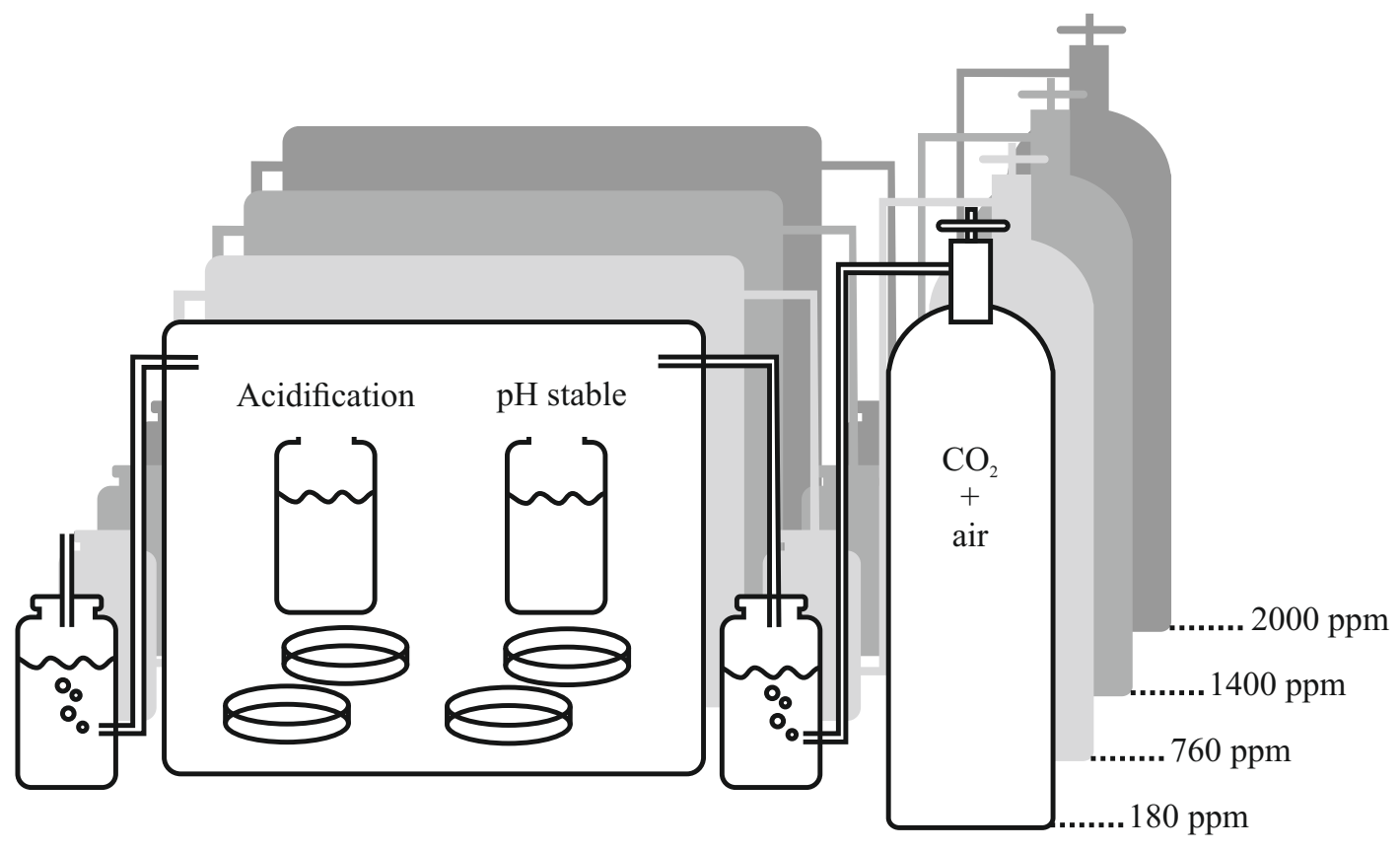




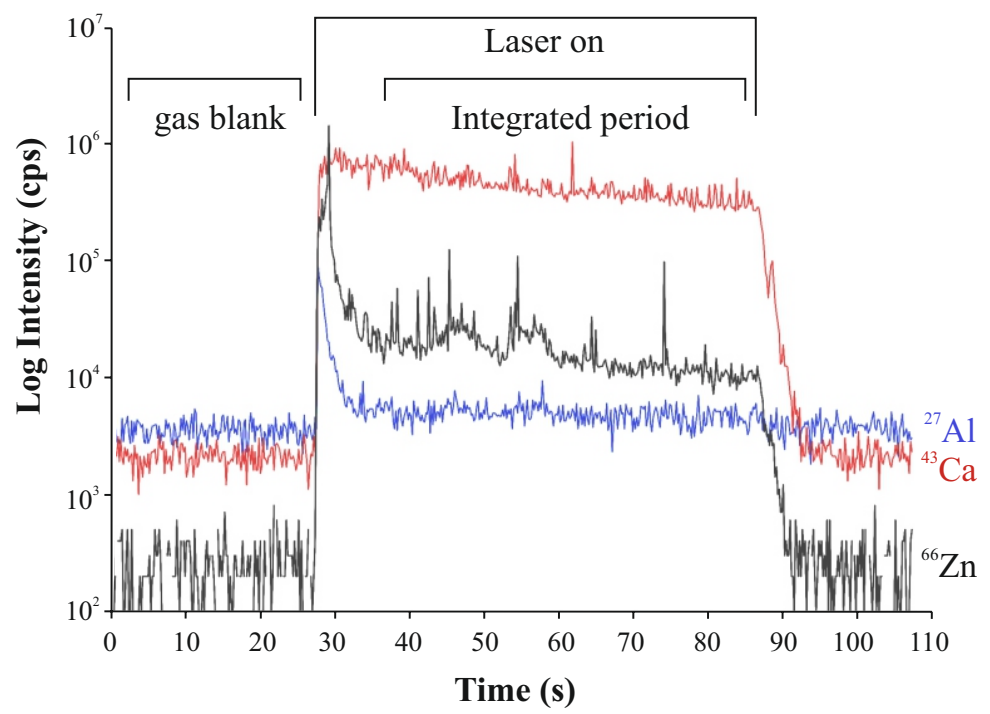



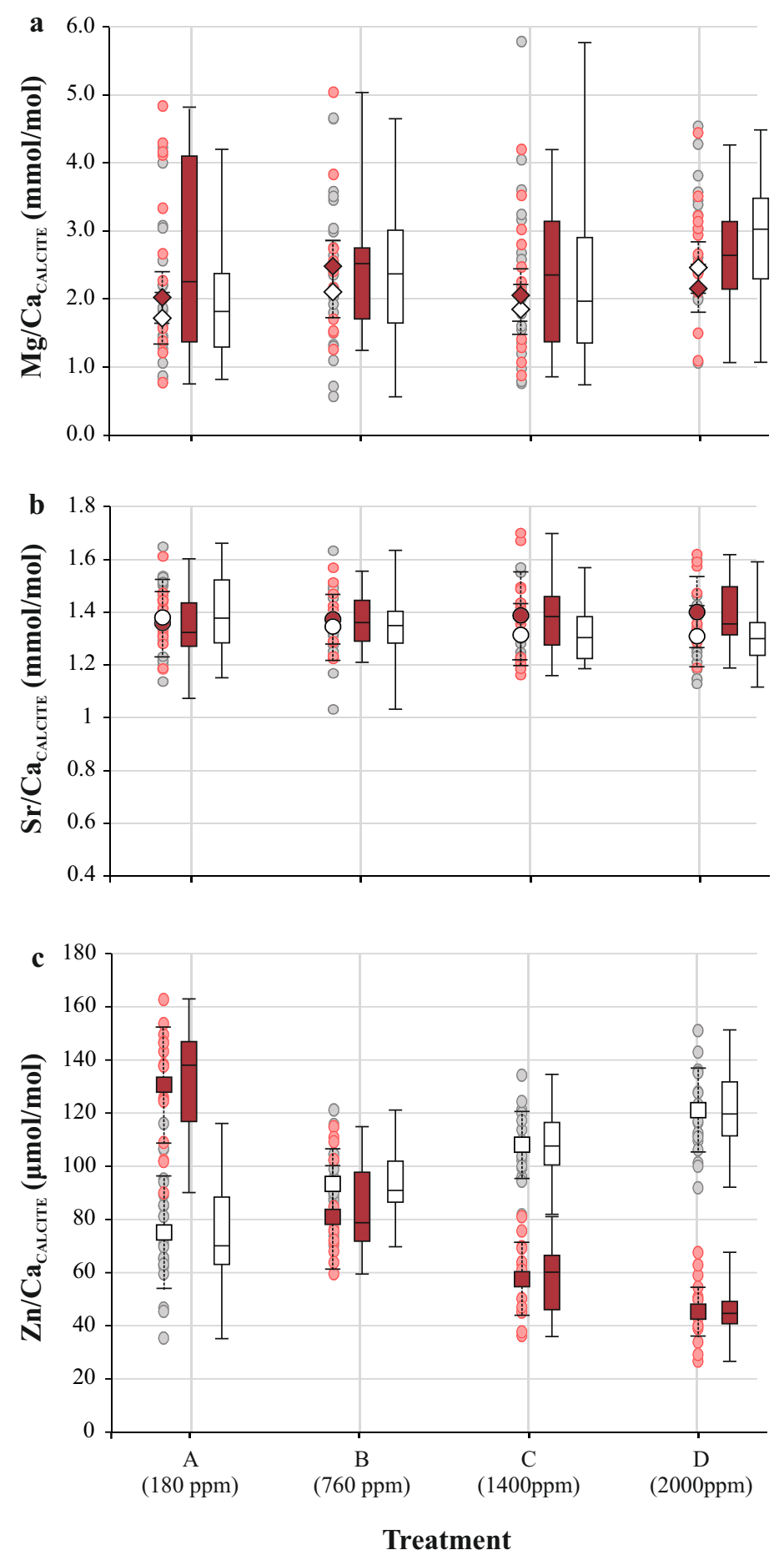

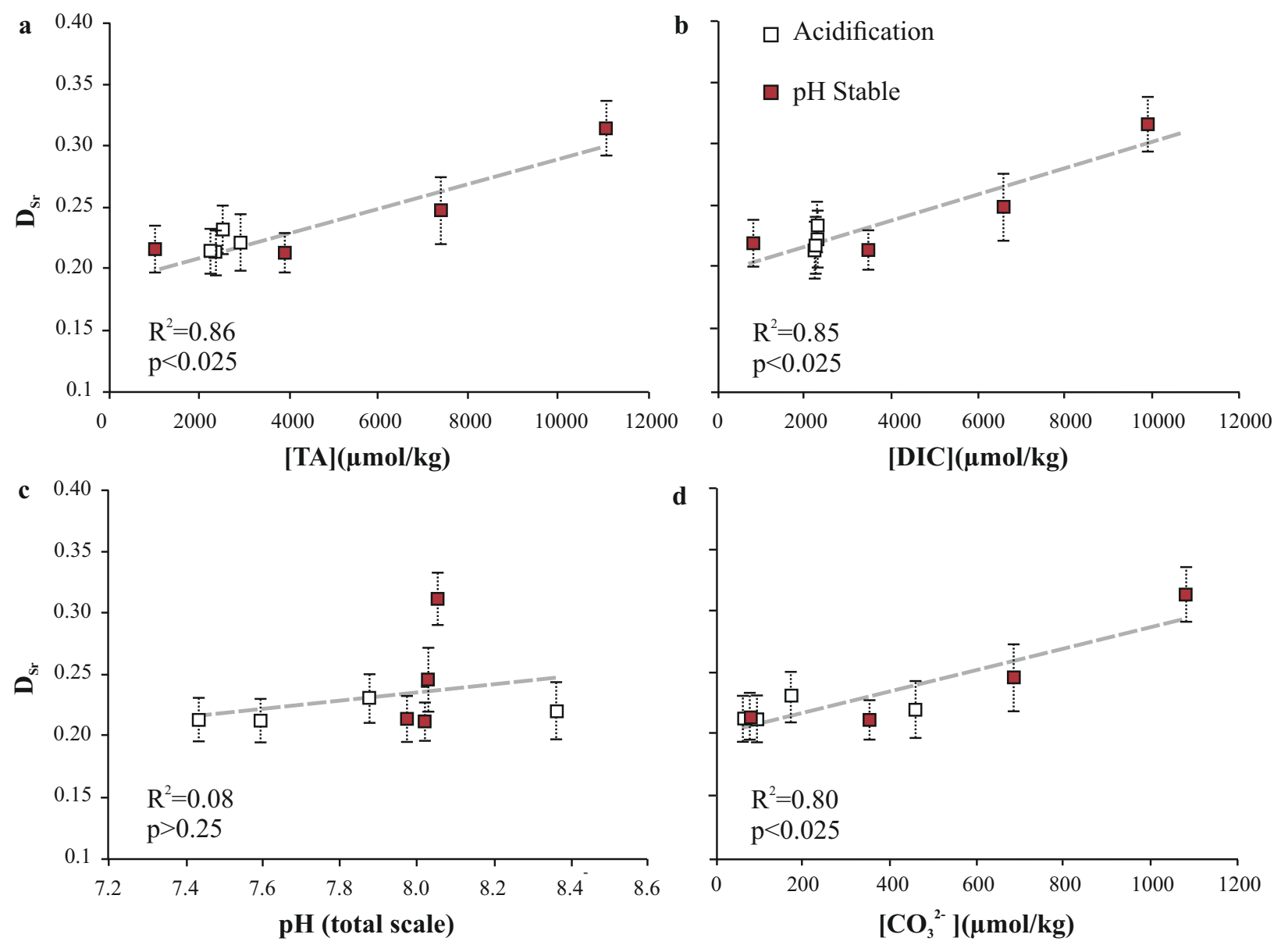

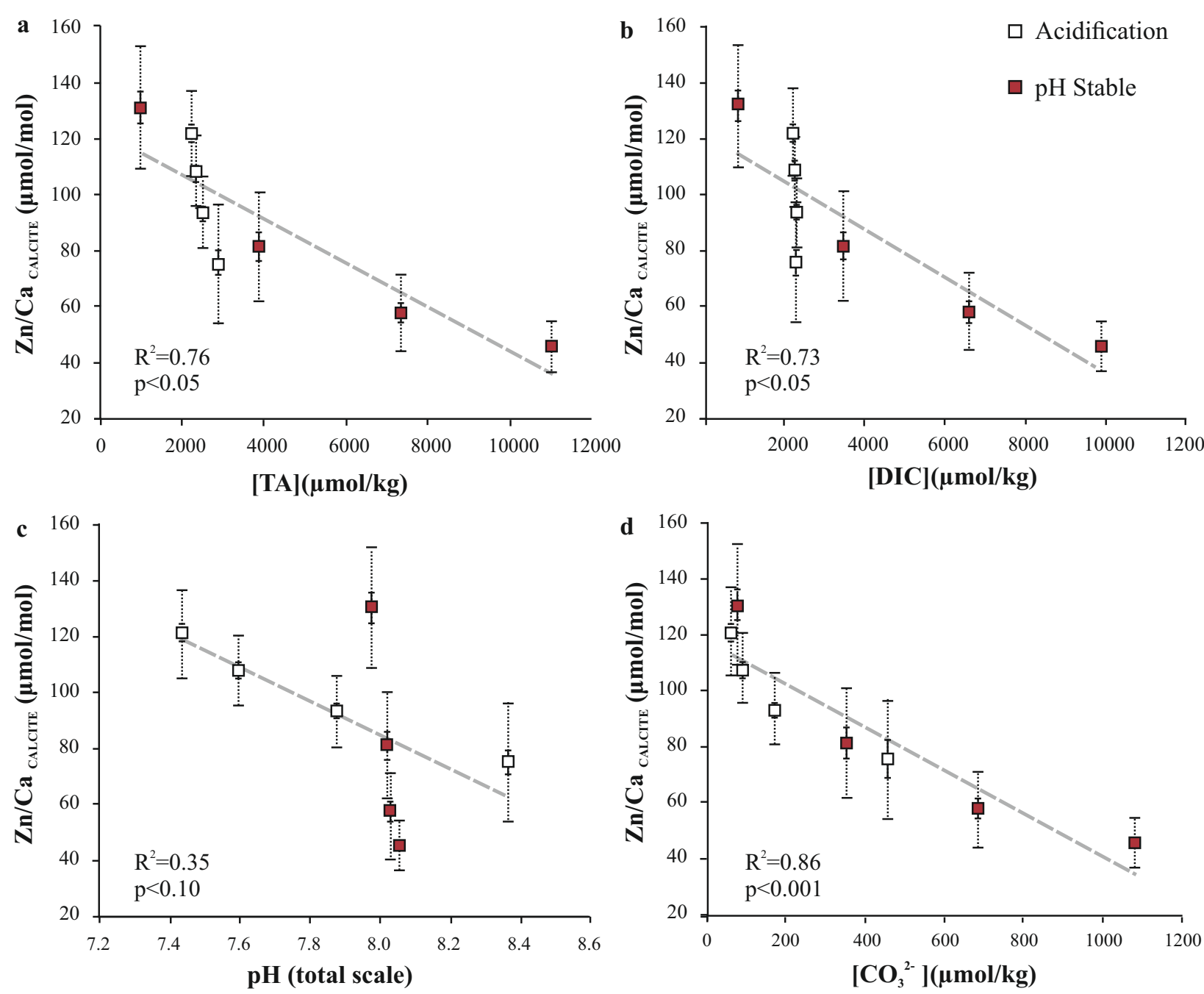


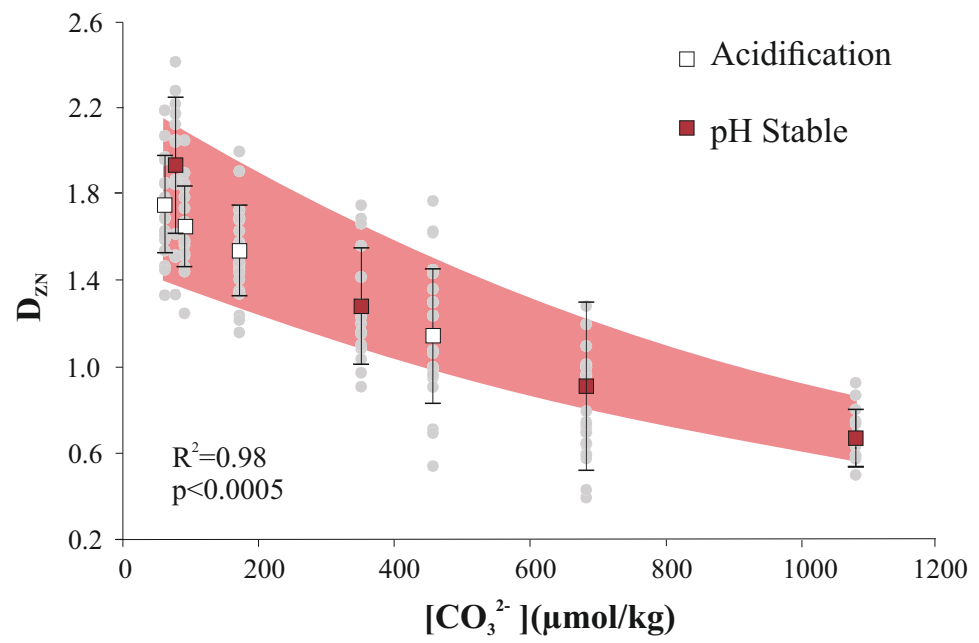



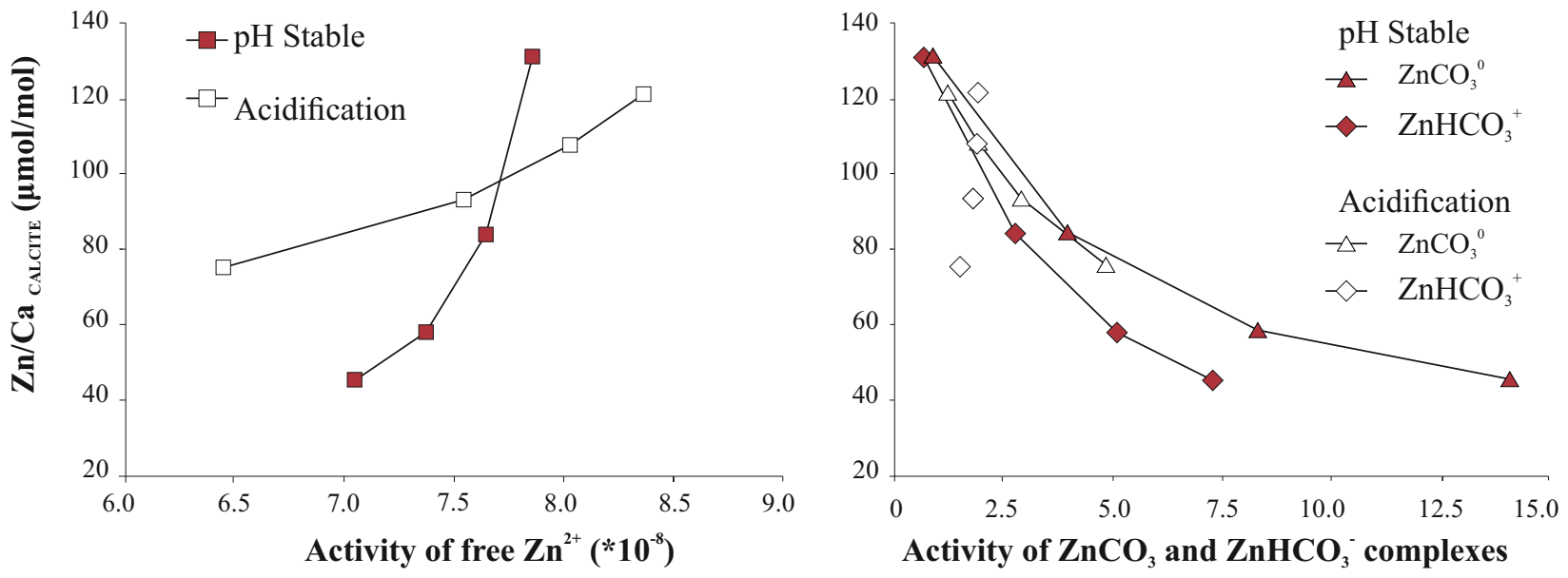